\title{
INTERTEMPORAL INCOME SHIFTING IN EXPECTATION OF LOWER CORPORATE TAX RATES: THE TAX REFORMS IN CENTRAL AND EASTERN EUROPE
}

\section{Boryana Madzharova}
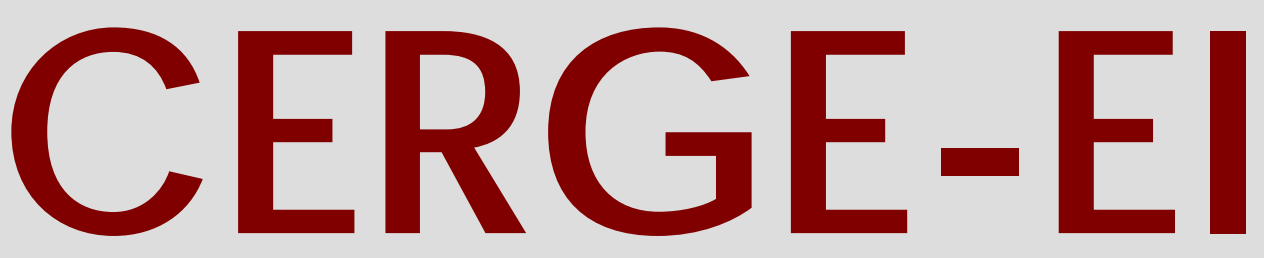

Charles University Centerfor Economic Research and Graduate Education Academy of Sciences of the Czech Republic Ec onomic s Institute 


\section{Working Paper Series $\quad 462$ (ISSN 1211-3298)}

\section{Intertemporal Income Shifting in Expectation of Lower Corporate Tax Rates: The Tax Reforms in Central and Eastern Europe}

Boryana Madzharova

CERGE-EI

Prague, May 2012 
ISBN 978-80-7343-265-2 (Univerzita Karlova. Centrum pro ekonomický výzkum a doktorské studium)

ISBN 978-80-7344-257-6 (Národohospodářský ústav AV ČR, v.v.i.) 


\title{
Intertemporal Income Shifting in Expectation of Lower Corporate Tax Rates: The Tax Reforms in Central and Eastern Europe *
}

\author{
Boryana Madzharova ${ }^{\dagger}$
}

\begin{abstract}
This paper examines if firms shift income out of years with high corporate tax rates into years when tax cuts are anticipated. Such intertemporal shifting can be one explanation for the stability of corporate tax revenues in Central and Eastern Europe, despite the major decline in the corporate tax rates and overall narrowing of the tax base starting in the late 90s. Using firm-level panel data for Bulgaria, the Czech Republic, Hungary, Poland, Romania and Slovakia from 1999 to 2005, the estimates indicate that the lower corporate tax rates induced a considerable increase in taxable income. Most of this increase, however, was due to short-term shifting of income to years with lower tax rates leading to non-transitory responses ranging from zero to .151, depending on the specification employed. Splitting the sample by firm size shows that income shifting is an appealing tax saving strategy for small and to a lesser extent medium-sized enterprises, but not for big firms. A further disaggregation by country reveals that the driving country behind the results is Romania.
\end{abstract}

Keywords: Corporate tax, Income Shifting, Tax reforms, Central and Eastern Europe JEL Classification: H25; H32; D32

\footnotetext{
*I wish to thank Libor Dušek, Jan Kmenta, Jan Hanousek, and Stěpán Jurajda for useful comments. Any remaining errors are mine.

${ }^{\dagger}$ CERGE-EI is a joint workplace of the Center for Economic Research and Graduate Education, Charles University, and the Economics Institute of the Academy of Sciences of the Czech Republic. Politickych veznu 7, 11121 Prague 1, Czech Republic, e-mail: Boryana.Madzharova@cerge-ei.cz.
} 


\begin{abstract}
Abstrakt
Tento článek zkoumá, zda firmy přesouvají př́ijmy z roků s vysokými korporátními daňovými sazbami do roků, kdy je očekáváno snižování daní. Takové intertemporální přesuny mohou vysvětlit stabilitu příjmů z korporátních daní ve střední a východní Evropě, navzdory značnému poklesu korporátních daňových sazeb a celkovému zúžení daňové základny, které začaly na konci devadesátých let. Odhady využívají panelová data na úrovni firem z Bulharska, České republiky, Mad'arska, Polska, Rumunska a Slovenska od roku 1999 do roku 2005 a naznačují, že nižší korporátní daňové sazby vedly k značnému navýšení zdanitelných př́ijmů. Většina z tohoto nárůstu byla však dána krátkodobými přesuny př́ijmů do roků s nižšími sazbami, což vedlo k nepřechodným odezvám v rozmezí od nuly do .151, v závislosti na užité specifikaci. Rozdělení vzorku podle velikosti firem ukazuje, že přesun př́jjmů je přitažlivým způsobem pro daňové úspory u malých a v menší míře středně velkých firem, ne ale u velkých firem. Další disagregace výsledků podle zemí ukazuje, že tyto výsledky jsou dány Rumunskem.
\end{abstract}




\section{Introduction}

Over the last three decades, as part of a broader shift towards indirect taxation and due to intensified international competition, many European Union (EU) economies decreased their statutory corporate income tax (CIT) rates. In the years between 2000 to 2009, a particularly intense period of corporate tax reform, the old Member States lowered the CIT rate by 8.32 percentage points (pp) on average and collected $1.27 \mathrm{pp}$ lower revenue as a percent of GDP in 2009 compared to 2000. The countries joining the EU in and after 2004, i.e., the Baltic countries, the Czech Republic, Poland, Slovakia, Hungary, Slovenia, Cyprus, Bulgaria and Romania undertook even larger cuts of 10.12 pp on average. Yet, average proceeds increased by $0.17 \mathrm{pp}$.

The pattern of falling rates and rising revenues has generated much research on whether the tax cuts generated their own revenue, or the broad reforms simply expanded the tax base. Devereux et al. (2004), for example, focus on the UK, concluding that while base-broadening can, to some degree, explain the strength of the UK's corporate tax revenues in the 1990s, the bulk of the increase was due to the rising importance and profitability of the financial sector. A more general analysis of the OECD countries is performed by Clausing (2007), who finds positive statistically significant effects of the rate of profitability and the corporate share on collected revenues.

Piotrowska and Vanborren (2008) show that the increasing rate of corporatisation is the driving factor behind growing revenues. Their finding is corroborated by Da Rin et al. (2011), who demonstrate that a lower CIT rate leads to higher entry rate.

While many aspects of tax reforms and firm behaviour have been studied to evaluate their revenue impacts, the intertemporal shifting of income by firms within a jurisdiction in expectation of lower future CIT rates has received little attention in the economic literature. This is surprising, given that, if the presence of income shifting is not considered, the deadweight loss of the corporate tax is likely to be overestimated owing to the fact that income shifting does not reflect permanent changes in firms' behaviour with real distortionary consequences but is a short-term transfer of revenue over time (Slemrod, 1995).

I use firm-level panel data for six Central and Eastern European (CEE) countries, namely Bulgaria, the Czech Republic, Hungary, Poland, Romania and Slovakia for the period 1999-2005, to test if taxable income was shifted to years with lower expected CIT rates. Common for these countries are the dynamic tax reforms starting in the early 2000s, characterised not only by cuts in the statutory tax rates, but also by extensive changes in the tax base and investment allowances. The announcement of the reforms 
was usually made in advance and, as King (1974) points out, such announcements can have significant effects on investment behaviour and taxable income reports, thus being a policy tool in their own right.

Deferral of income declaration or acceleration of expense recognition in years before a main tax reduction can generate sizeable tax savings. Thus, the shifting of taxable income to years with lower corporate tax rate would manifest as higher revenue collections. However, many other factors can account for rising corporate tax revenues. Therefore, before testing the income shifting hypothesis, I examine the tax reforms in CEE in greater detail in order to better comprehend the role adjustments in the tax base, firms' profitability, and the size of the corporate sector play in explaining revenue dynamics.

Instead of widening tax bases, tax reductions in CEE were generally accompanied by more generous capital allowances and numerous tax incentives and credits, especially targeting the manufacturing sector and new investment. Moreover, although there was an increase in firm profitability in some countries (Poland, Slovakia), higher entry rate (the Czech Republic), and an increased share of the corporate sector (Romania), these trends were not so pronounced as to entirely explain unchanging or raising tax revenue, given the major CIT cuts. This suggests that other factors, such as curtailing of the shadow economy and income shifting, could have had a major influence on revenue collections in CEE.

The empirical analysis begins with the construction of effective corporate income tax rates based on the methodology of Devereux and Griffith (2003) and explores how elastic firms' taxable income is to changes in these tax measures. I do not, however, focus only on the current effect, but separate the long-run and the short-run firms' responses in order to detect earnings management. Specifically, in addition to contemporaneous tax terms, lagged and leading tax rates are included, which capture adjustments in TI stemming from firms' expectations about future net-of-tax shares.

In the short-run taxable income is found to be very responsive to cuts in the CIT rate. In particular, in the richest specification, a $1 \%$ increase in the log of the current net-of-tax share increases the taxable income-total assets ratio by 0.0134 . To put this number into perspective, note that the average TI to total asset ratio for the firms used in the paper from 1999 to 2005 is between 0.07 and 0.1. The results suggest, however, that a large part of the increase in TI comes from the shifting of income across years to take advantage of tax rate cuts. There are positive and significant long-term effects in most specifications, although with some particular dummy structures, this effect becomes not significantly different from zero.

Disaggregating the data by firm size reveals that the sizeable coefficients on the 
lagged, leading and current tax rates are almost entirely driven by small enterprises, and become modest for medium enterprises, while for big firms the contemporaneous effect is estimated to be negative. This puzzling finding may be explained by the high political costs of income shifting faced by big firms, but also with the numerous other earnings management instruments and tax incentives available to them. The intertemporal shifting of income, therefore, appears to be a more appealing tax saving strategy to smaller companies that do not possess the wide array of tax management tools a big corporation can exploit.

A further disaggregation by country shows that Romanian firms exhibit the biggest anticipatory response, followed by the Czech Republic and Poland. For Bulgaria, Hungary and Slovakia, a negative effect of the current net-of-tax share is estimated.

The rest of the paper is structured as follows: Section 2 proceeds with a brief overview of the literature on intertemporal income shifting; Section 3 outlines the tax reforms in CEE, while Section 4 describes the data and the empirical strategy. Results are presented in Section 5, and Section 6 concludes.

\section{Analyses of income shifting in the literature}

Different tax rates can arise within the same tax base over time. One explanation for the volatility of corporate tax revenue can therefore be the intertemporal shifting of income, provided that tax cuts were anticipated. Goolsbee (2000) studies intertemporal shifting for high income executives through the timing of stock options in the context of the Omnibus Budget Reconciliation Act of 1993 (OBRA). Heim (2006) estimates the elasticity of taxable income for individuals and like Goolsbee (2000) controls for future net-of-tax shares, but also accounts for the effect of lagged taxes. Overall, Heim (2006) finds negative and significant long-term responses.

Revenue management by firms in expectation of lower corporate tax rates is examined by Guenther (1994) and Scholes et al. (1992) for the Tax Reform Act of 1986 (TRA86). In particular, Guenther (1994) looks at adjustments in current accruals (CA) as an indicator of revenue management. CA are defined as the change in the difference between a firm's current assets and current liabilities from year $t-1$ to year $t$. The author focuses on CA because they are discretionary accruals, enabling managers to transfer earnings between periods by accelerating expenses or deferring the recognition of revenue. ${ }^{1}$ Since taxable income is not observable by researchers, Guenther (1994) demonstrates that deductibility

\footnotetext{
${ }^{1}$ If the tax rate is to be increased, firms have an incentive to accelerate revenue and defer expenses in order to shift taxable income in the year before the tax increase.
} 
of an accrued expense or deferral of revenue for tax purposes is sufficient but not a necessary condition for the accrual of the expense or the deferral of the revenue for financial statement purposes. Thus, it is likely that deferral of taxable income translates into deferral of financial statement income.

The author estimates significantly negative current accruals for large firms for the year before the tax rate reduction, which suggests that accounting earnings were managed in response to changes in the statutory tax rate. The same analysis is performed by Roubi and Richardson (1998), who find evidence of firms' management of discretionary accruals in Canada and Singapore, and to a lesser extent, in Malaysia.

Scholes et al. (1992) use the fact that, due to the phase-in character of tax rate decreases of TRA86, different fiscal year-end firms faced different future corporate tax rates to estimate their propensity to shift income between quarters. Their results show that the shifting of gross margin and selling, general and administrative expense during quarters before the tax cuts, resulted in $\$ 459,000$ in tax savings, on average, although the shift was not uniform across income and expense items.

The shifting of income can also be captured by studying the responsiveness of TI to tax rates. Few studies have estimated the elasticity of TI w.r.t. the corporate income tax and generally, without controlling for income shifting. Overall, this literature is small, primarily because the taxable income elasticity approach for individuals does not transfer entirely to the CIT. ${ }^{2}$ Gruber and Rauh (2007) use industry-level data on publicly traded corporations in the US and find a modest elasticity of 0.2. For Germany, ETI is estimated by Dwenger and Steiner (2012) who use detailed tax return data on loss carryforwards to estimate effective tax rates for individual firms.

\section{Corporate Tax Reforms in CEE}

\subsection{Statutory tax rates}

Table 1 shows the evolution of the statutory CIT rates for the six countries under consideration. With the exception of Hungary, these countries maintained relatively high rates in the range of $34 \%$ to $40 \%$ in 1999, but from 2000 onwards an overall decline is observed. Romania and Slovakia slashed the CIT rate in stepwise reductions ending up with rates of $16 \%$ and $19 \%$ in 2007 , respectively, which is about 21 pp below their level in

\footnotetext{
${ }^{2}$ As Jane Gravelle points out in her critique of Gruber and Rauh (2007), adjustments in firms' TI reflect a complex combination of factor and product substitution elasticities, capital intensities, depreciation and other factors, all of which are complications, which do not arise in the case of personal income taxation.
} 
Table 1: CHANGES IN STATUTORY TAX RATES AND CORPORATE REVENUE

\begin{tabular}{|c|c|c|c|c|c|c|c|c|c|c|}
\hline & 1999 & 2000 & 2001 & 2002 & 2003 & 2004 & 2005 & 2006 & 2007 & $\triangle$ \\
\hline $\mathrm{BG}$ & $\begin{array}{l}34.3 \\
28.0\end{array}$ & $\begin{array}{l}32.5 \\
28.0\end{array}$ & $\begin{array}{l}28.0 \\
23.5\end{array}$ & 23.5 & 23.5 & 19.5 & 15.0 & 15.0 & 10.0 & -24.3 \\
\hline CR \% GDP & 3.1 & 2.7 & 3.8 & 3.0 & 2.8 & 2.5 & 1.8 & 2.1 & 4.4 & 1.3 \\
\hline $\begin{array}{l}\mathrm{CZ} \\
\mathrm{CR} \% \mathrm{GDP}\end{array}$ & $\begin{array}{c}35.0 \\
3.8\end{array}$ & $\begin{array}{c}31.0 \\
3.5\end{array}$ & $\begin{array}{c}31.0 \\
4.1\end{array}$ & $\begin{array}{c}31.0 \\
4.3\end{array}$ & $\begin{array}{c}31.0 \\
4.6\end{array}$ & $\begin{array}{c}28.0 \\
4.7\end{array}$ & $\begin{array}{c}26.0 \\
4.5\end{array}$ & $\begin{array}{c}24.0 \\
4.8\end{array}$ & $\begin{array}{c}24.0 \\
5.0\end{array}$ & $\begin{array}{c}-11.0 \\
1.2\end{array}$ \\
\hline $\begin{array}{l}\mathrm{HU} \\
\mathrm{CR} \% \mathrm{GDP}\end{array}$ & $\begin{array}{c}19.6 \\
2.3\end{array}$ & $\begin{array}{c}19.6 \\
2.2\end{array}$ & $\begin{array}{c}19.6 \\
2.3\end{array}$ & $\begin{array}{c}19.6 \\
2.3\end{array}$ & $\begin{array}{c}19.6 \\
2.2\end{array}$ & $\begin{array}{c}17.6 \\
2.1\end{array}$ & $\begin{array}{c}17.5 \\
2.1\end{array}$ & $\begin{array}{c}17.5 \\
2.3\end{array}$ & $\begin{array}{c}21.3 \\
2.8\end{array}$ & $\begin{array}{l}1.7 \\
0.5\end{array}$ \\
\hline $\begin{array}{l}\mathrm{PL} \\
\mathrm{CR} \% \mathrm{GDP}\end{array}$ & $\begin{array}{c}34.0 \\
2.4\end{array}$ & $\begin{array}{c}30.0 \\
2.4\end{array}$ & $\begin{array}{c}28.0 \\
1.9\end{array}$ & $\begin{array}{c}28.0 \\
2.0\end{array}$ & $\begin{array}{c}27.0 \\
1.8\end{array}$ & $\begin{array}{c}19.0 \\
2.2\end{array}$ & $\begin{array}{c}19.0 \\
2.5\end{array}$ & $\begin{array}{c}19.0 \\
2.4\end{array}$ & $\begin{array}{c}19.0 \\
2.8\end{array}$ & $\begin{array}{c}-15.0 \\
0.4\end{array}$ \\
\hline $\begin{array}{l}\mathrm{RO} \\
\mathrm{CR} \% \mathrm{GDP}\end{array}$ & $\begin{array}{c}38.0 \\
3.8\end{array}$ & $\begin{array}{c}25.0 \\
3.0\end{array}$ & $\begin{array}{c}25.0 \\
2.5\end{array}$ & $\begin{array}{c}25.0 \\
2.6\end{array}$ & $\begin{array}{c}25.0 \\
2.8\end{array}$ & $\begin{array}{c}25.0 \\
3.2\end{array}$ & $\begin{array}{c}16.0 \\
2.7\end{array}$ & $\begin{array}{c}16.0 \\
2.8\end{array}$ & $\begin{array}{c}16.0 \\
3.1\end{array}$ & $\begin{array}{l}-22.0 \\
-0.7\end{array}$ \\
\hline $\begin{array}{l}\text { SK } \\
\text { CR \% GDP }\end{array}$ & $\begin{array}{c}40.0 \\
3.1\end{array}$ & $\begin{array}{c}29.0 \\
2.6\end{array}$ & $\begin{array}{c}29.0 \\
2.6\end{array}$ & $\begin{array}{c}25.0 \\
2.5\end{array}$ & $\begin{array}{c}25.0 \\
2.8\end{array}$ & $\begin{array}{c}19.0 \\
2.6\end{array}$ & $\begin{array}{c}19.0 \\
2.7\end{array}$ & $\begin{array}{c}19.0 \\
2.9\end{array}$ & $\begin{array}{c}19.0 \\
3.0\end{array}$ & $\begin{array}{l}-21.0 \\
-0.1\end{array}$ \\
\hline $\begin{array}{l}\text { EU-17 } \\
\text { CR \% GDP }\end{array}$ & $\begin{array}{c}35.5 \\
3.3\end{array}$ & $\begin{array}{c}35.5 \\
3.4\end{array}$ & $\begin{array}{c}33.8 \\
3.3\end{array}$ & $\begin{array}{c}32.6 \\
3.3\end{array}$ & $\begin{array}{c}31 \\
3.0\end{array}$ & $\begin{array}{c}30.5 \\
3.0\end{array}$ & $\begin{array}{l}29 \\
3.1\end{array}$ & $\begin{array}{c}28.6 \\
3.3\end{array}$ & $\begin{array}{c}27.7 \\
3.6\end{array}$ & $\begin{array}{c}-7.8 \\
0.3\end{array}$ \\
\hline
\end{tabular}

Note: All tax rates are in \%. CR \% GDP shows corporate tax revenue as a percent of the respective country's GDP. The last column lists the percentage points change from 1999 to 2007. Until 2001, in addition to the standard rate, Bulgaria had a lower CIT rate for companies with TI below a legally stipulated threshold.

Source: Ernst $\&$ Young (Various years); European Commission (Various years)

1999. Bulgaria, the Czech Republic, and Poland engaged in more frequent, albeit smaller annual cuts, bringing the CIT rate substantially below the EU-15 average, apart from the Czech Republic, whose rate was only about 4 pp lower than the EU-15's in 2007.

A Romanian firm that deferred $\$ 1$ of TI from 1999 to 2000, gained 20\%, given the 13 pp fall in the CIT rate. Similar tax savings could be realised in Slovakia, and over the longer-term, in Bulgaria, the Czech Republic and Poland.

Compared to other CEE countries, Hungary had a low CIT rate of $19.6 \%$ as early as 1997, which was first reduced in 2004 to $17.6 \%$. Thus, Hungary is one of the few EU countries exhibiting little dynamics in its statutory CIT rate. The rates in Poland, Romania, and Slovakia did not change after 2005, so the bulk of the reforms took place between 1999 and 2005.

Despite the considerable fall in the statutory rates, corporate tax revenues in CEE as a proportion of GDP remained stable and even increased in some countries (Table 1). From 1999 to 2007, the Czech Republic lowered its CIT rate by 11 pp, yet it collected 1.2 pp higher revenue as a \% of GDP in 2007 than it did in 1999. Overall, the Czech Re- 
public exhibited buoyant and steadily growing corporate tax collections accompanied by gradually declining statutory rate. Revenue was more volatile in Bulgaria. An interesting trend is that revenue collections dip in the year before a tax cut only to bounce back in the year of the tax cut. This is valid for the 2000-2001 tax decrease and especially for the 2006-2007 5 pp cut, which more than doubled revenue in 2007. The same tendency is observed in Poland, where collections did not change from 1999 to 2000, while the 8 pp tax cut from 2003 to 2004 increased revenue. Tax cuts in Romania and Slovakia were usually followed by a slight drop in revenue, but in general, collections displayed little fluctuation, remaining especially stable in Hungary. ${ }^{3}$

\subsection{Tax base}

In contrast to other EU countries, which broadened the tax base and closed loopholes to make tax cuts revenue-neutral, the six CEE countries considered in this paper narrowed their tax bases by introducing various tax incentives and more generous capital allowances, primarily after 1999. ${ }^{4}$ Table 2 summarises some of the most important tax incentives, whose effect can later be accounted for in the data. ${ }^{5}$ In general, most tax breaks applied to the manufacturing sector, but also overall to businesses operating in areas with high unemployment.

The Czech Republic, for example grants a ten year income tax holiday for companies investing certain funds in manufacturing as well as provides job-creation and retraining grants. Although few firms qualified for this policy in its starting years, currently many foreign and domestic investors take advantage of the tax breaks. Other countries chose to stimulate smaller businesses. Romania, for instance, implemented special provisions for small and medium enterprises and microenterprises, while Bulgaria offers 100\% corporate income tax relief if a company operates in a high unemployment region. Besides manufacturing, Hungary also supports its hoteling industry and Slovakia has numerous incentives for foreign investors. Since 1995, Poland created seventeen special economic zones (currently fourteen), in which companies can benefit from tax exemptions provided

\footnotetext{
${ }^{3}$ It is worth mentioning that the Baltic countries, although not studied in this paper, experienced $100 \%$ increase in revenue through modest cuts in the CIT rates. From 2000 to 2009, for example, rates in Estonia and Lithuania fell by 5 and 4 pp, respectively. Collections rose from $0.9 \%$ (2000) to $1.8 \%$ (2009) in Estonia, and from $0.7 \%$ to $1.8 \%$ in Lithuania. A similar trend is observed in Latvia.

${ }^{4}$ In all six countries, indirect taxation is gradually becoming one of the biggest sources of government revenue and certainly of greater importance than the CIT. The shift from direct to indirect taxation is not limited to CEE, however, and is happening, to a varying degree, across all EU countries. This shift is acknowledged and in fact encouraged by the European Commission (2010). The increasing reliance on indirect taxes can be a possible explanation of why corporate tax cuts were not accompanied by a tax base expansion.

${ }^{5}$ Except loss carryforward.
} 


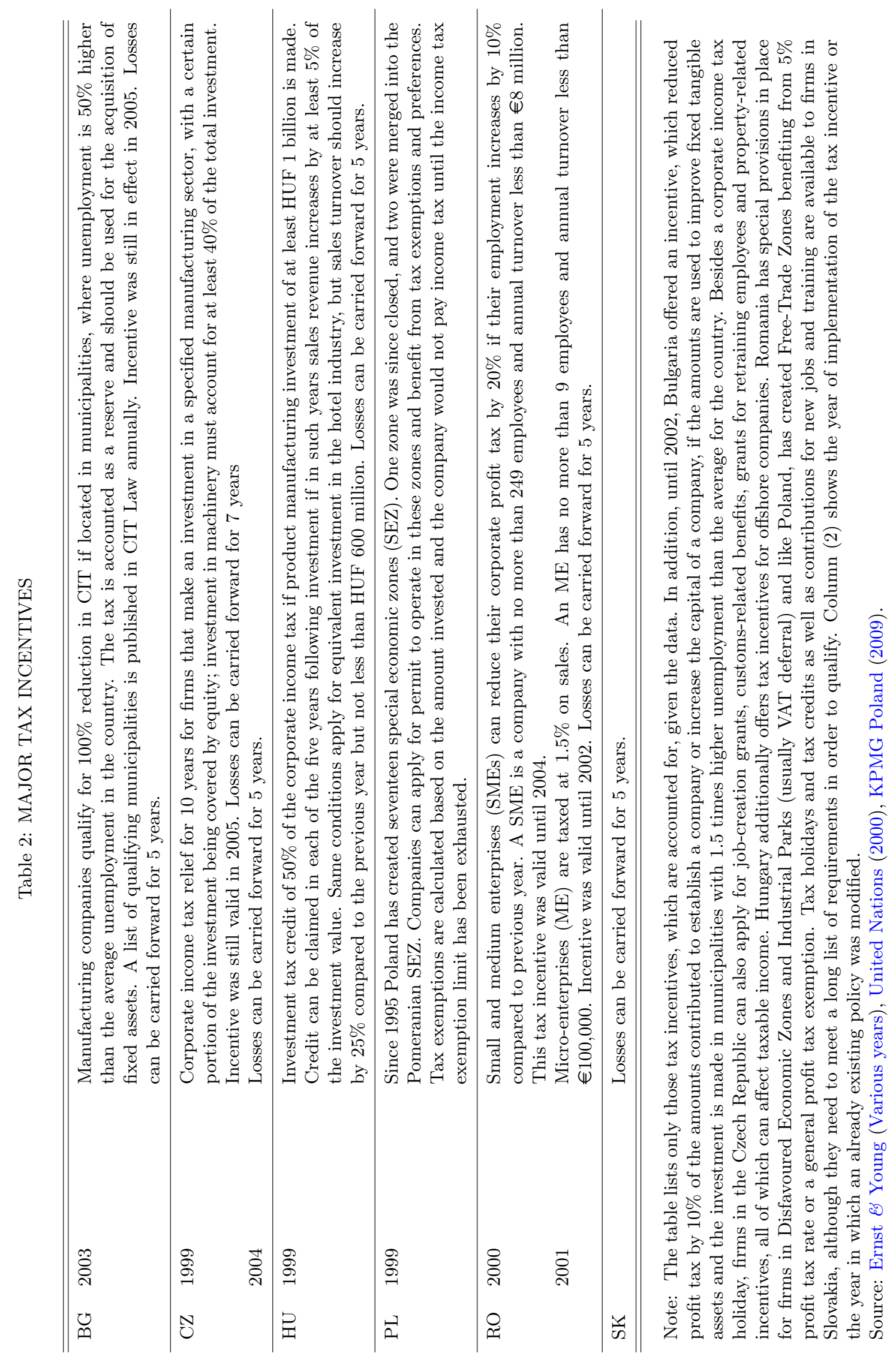




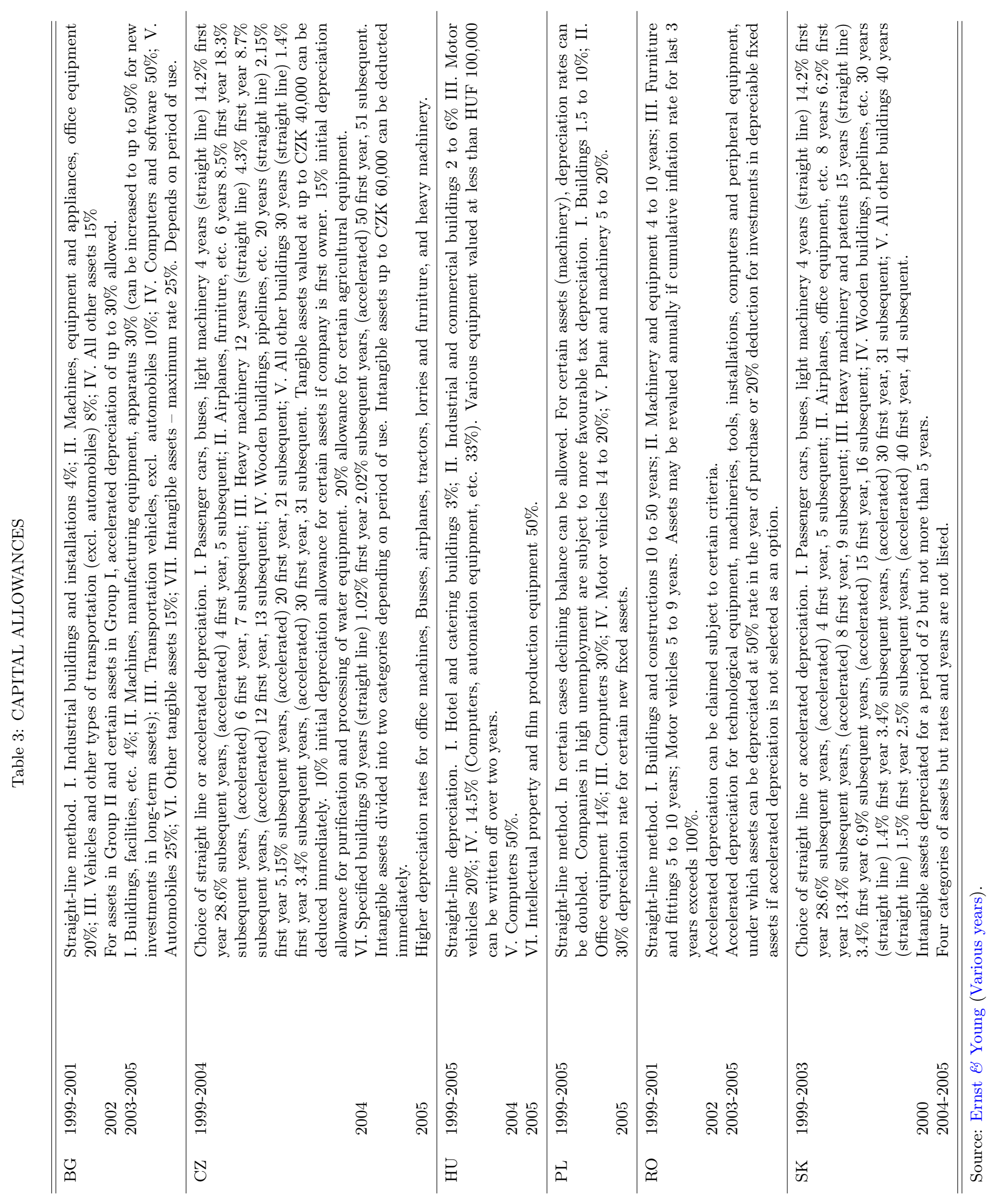


they obtain a permit from the zoning authorities. Table 2 and Appendix A.2 describe the tax incentives in greater detail.

With regard to capital allowances, all six countries maintained the yearly writedown allowances at their 1999 level (Table 3). Gradually, more detailed asset categories were introduced that generally benefited from higher depreciation rates, a development applying especially to the IT and communications sector. Provisions for intangible assets were also established. In 2003 Bulgaria increased the depreciation rates for some assets including plant and machinery, followed by the Czech Republic in 2005. Romania allowed for an accelerated depreciation rate at $50 \%$ in the year of purchase for technological equipment and other machinery in service after 2002.

Due to the limitations of the data, a single definition of taxable income cannot be adopted in the empirical analysis that follows. It is therefore important to establish that the definition of TI has not changed in such a way that TI would have grown for reasons unrelated to tax rates or firms' profitability.

While the definition of taxable income was indeed altered in all countries, it was mostly in the direction of increasing deductible expenses. In Bulgaria, the number of new provisions reducing the financial result was far greater than the ones raising it. The list of deductible expenses in Hungary, Poland and the Czech Republic remained virtually the same, with the exception of a new provision introduced in 2004 in the Czech Republic, stipulating that the purchase cost of intangible assets up to CZK60,000 can be deducted immediately (Ernst \&6 Young, Various years). Romania followed a balanced approach in modifying firms' taxable income. For example, up to $1.5 \%$ of total salary cost could be deducted in 2005 compared to $2 \%$ in 2004 , but in 2005 permanent establishments could deduct $\mathrm{R} \& \mathrm{D}$, and management and administration expenses up to $10 \%$ of taxable salaries.

Given the described policies and the falling CIT rates, the strength of corporate tax revenues cannot be explained by expansions in the tax base. It is certainly possible, however, that enhancement of tax administrations' enforcement and collection abilities could have generated additional revenue by driving more firms out of the shadow economy. According to the World Bank Worldwide Governance Indicators, regulatory quality, which incorporates the effectiveness of the tax collection system, has improved tremendously in CEE for the period 1999-2005. Nevertheless, according to the indicators, there are mixed signals concerning the control of corruption, which has not exhibited marked advancement, and in the case of Poland, has actually worsened with time. 


\subsection{Rate of incorporation and profitability}

Even if the tax base became narrower, lower CIT rates could have promoted a higher rate of incorporation and the growth of already established businesses. Further, firms may have become more profitable due to non-tax reasons. To examine if this is the case, I study changes in the profit rate of corporations, the share of the corporate sector in GDP and the number of firms per capita. I follow Clausing (2007) and construct a rate of profitability measure by dividing corporations' aggregate net operating surplus by corporate value added. Corporate value added scaled by GDP serves as a measure of the share of the corporate sector. Finally, the number of firms by industry as well as population statistics are taken from OECD's Structural Business Statistics and Eurostat.

Figure 1 shows the number of enterprises per capita in the non-financial sector from 1999 to 2005. The number of firms relative to the population increased in Romania and remained virtually unchanged in Hungary, Slovakia, and Bulgaria. There was a substantial jump in the entry of firms in the Czech Republic between 2001 and 2002, with the time series stabilising at the higher level post $2002 .{ }^{6}$ In general, the Czech Republic has markedly higher businesses-to-population ratio than the remaining five countries. In contrast, Poland experienced an overall decline in businesses both in absolute and per capita level.

Trends in profitability are depicted in Figure 2. Looking in more detail at the sectoral differences, the mining and quarrying as well as the electricity, gas, and water supply industries expanded in all countries, although their profitability was volatile - from negative in Poland, Slovakia and Hungary to steadily growing in the Czech Republic (Appendix A.1: Tables 11 and 12). ${ }^{7}$ The number of firms operating in the Real Estate and Business Services sector grew in all countries and its profitability remained stable.

Apart from the sectors mentioned above, the number of enterprises in Poland declined in all other industries, yet their profitability increased considerably. Piotrowska and Vanborren (2008) also find an increasing entry rate and corporate profit share for the Czech Republic and Poland, respectively. Overall, only Poland and Slovakia exhibit an upward tendency in the rate of profitability. ${ }^{8}$ Last but not least, the share of the corporate sector in GDP declined in Bulgaria, Hungary, and Slovakia, remained the same in Poland and the Czech Republic, and increased in Romania, as depicted in Figure 3.

\footnotetext{
${ }^{6}$ The entry rate could have been even higher as the change of the number of firms from one year to the next is a combination of both the birth and death rates of firms.

${ }^{7}$ For Romania, the data is only for the total number of firms.

${ }^{8}$ Figure 2 excludes the financial sector, but the trends do not change if this sector is considered.
} 
Figure 1: NUMBER OF ENTERPRISES PER CAPITA

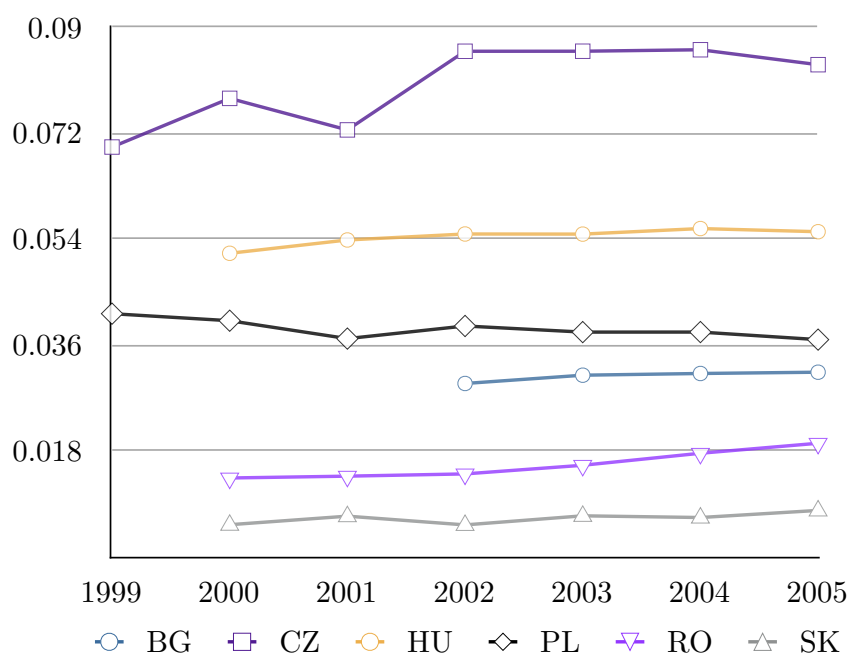

Figure 2: RATE OF PROFITABILITY

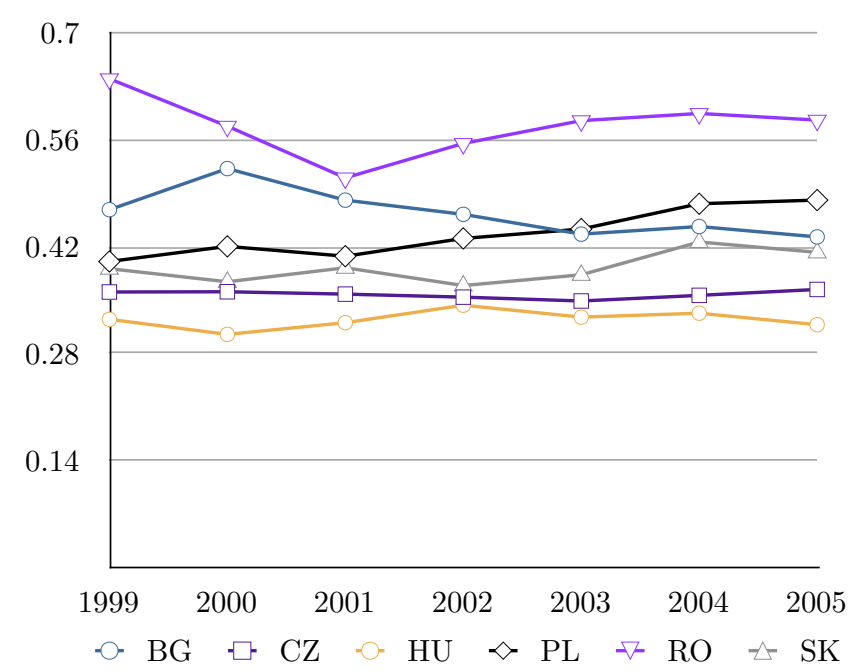

Figure 3: SHARE OF CORPORATE SECTOR IN GDP

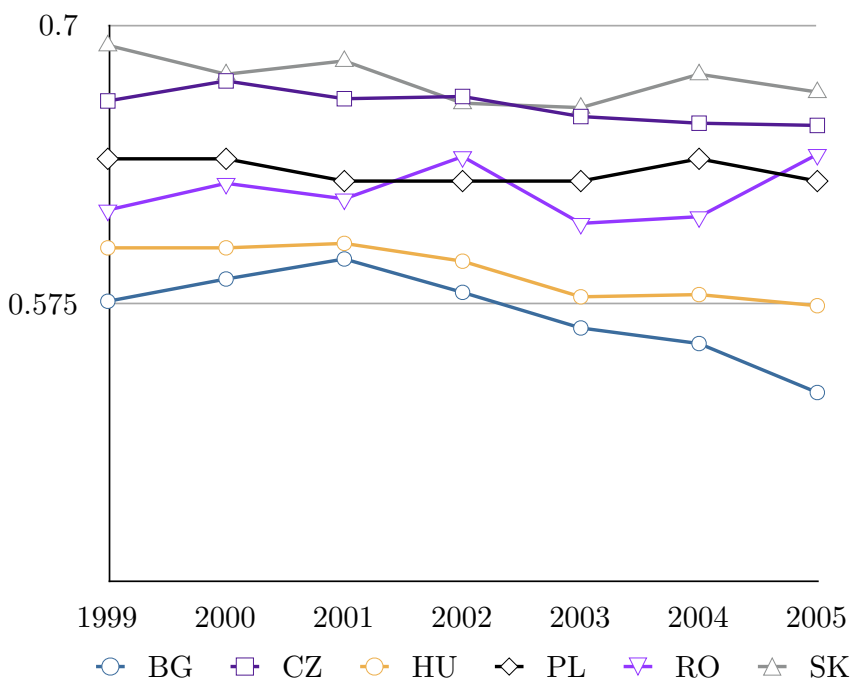




\section{Empirical Analysis}

\subsection{Data}

I use firm-level panel data from the comprehensive AMADEUS dataset for European companies compiled by Bureau van Dijk. The data consists of financial statements' variables as reported by firms. I consider data for the $6 \mathrm{CEE}$ countries discussed above, namely Bulgaria, the Czech Republic, Hungary, Poland, Romania, and Slovakia for the period 1999-2005. Earlier years are not included because AMADEUS's data coverage for CEE was limited before and even in 1999 and also because most tax reforms took place after 1999.

Sole proprietors, partnerships, societies, associations and non-profit organisations are excluded from the analysis, since some are non-corporate entities and others are subject to special tax provisions. For each country I keep public and private limited companies, branches of foreign corporations, as well as municipal and state companies, resulting in a dataset of 3,248,643 firm-year observations. If a firm has submitted both consolidated and unconsolidated statements, only the unconsolidated statement is considered in order to avoid repetitive firm observations (3,795 firm-year observations dropped). The sample is further restricted to include firms whose status is active, i.e., not in bankruptcy, dissolution, or liquidation, and that file a report at the end of the year (11,399 firm-year observations dropped).

I follow Klapper et al. (2006) and Da Rin et al. (2011) and exclude certain industries that are unlikely to manage taxable income or are subject to stricter regulations. In particular, I remove financial services (NACE2 65-66; 2,551 firm-year observations), public administration, education, and other social and personal services industries (NACE2 75, 80, 90, 91, 92, 95, 97, 99; 40,328 firm-year observations) as well as firms missing an industry classification (36,471 firm-year observations). Overall, there remain 51 different industries based on a NACE2 classification. I additionally drop observations with spells of missing values of taxes paid, cost of employees, profit/loss for the period and depreciation in the beginning and the end of each panel (1,112,893 firm-year observations), all of which are variables used later on in the calculation of effective tax rates.

All financial amounts are transformed into thousands of USD using AMADEUS's exchange rate from the local currency to USD at the fiscal year end of companies. By and large, the exchange rates exhibit little volatility, which will not affect the subsequent empirical estimation as all balance-sheet variables are scaled by total assets. The statutory tax rates for each country are described in Table 1, but before proceeding with computing taxable income, I need to identify firms that have utilised tax breaks, and 
therefore face lower or zero corporate tax rates. In the data, such firms usually appear as paying zero taxes due to tax incentives, yet it would be wrong to infer their taxable incomes to be zero.

Appendix A.2 describes in detail what types of firms qualify for tax incentives and how they are identified. All in all, approximately 600 major manufacturing firms from Bulgaria, the Czech Republic, Hungary and Poland qualify for some tax incentive. The number is much more substantial for Romania, since the incentives cover SMEs and microenterprises. About 9,000 companies per year (2000-2004) in Romania fulfil the SMEs incentive criteria and more than 70,000 firms in 2001 could use the microenterprises tax rate. Earnings before interest and tax (ebit) are used as a measure of taxable income in the case of a tax incentive, which enables the firm to pay no tax. If the incentive reduces the tax rate, then I simply assign the lower rate to the eligible firm.

\subsection{Computing firm-level effective tax rates}

The methodology of Devereux and Griffith (2003) is followed to compute effective average corporate tax rates (EATR) based on the net-present value (NPV) of a hypothetical investment project, calculated in the presence and absence of a tax. In particular,

$$
E A T R=\frac{R^{*}-R}{R^{*}}
$$

with $R^{*}$ being the NPV of the project without tax and $R$ - the NPV with tax. An attractive feature of this effective tax rate, as pointed out by Devereux and Griffith (2003), is that it constitutes a weighted average of the marginal effective tax rate for marginal investments, and the statutory tax rate for very profitable investments. $R$ is derived in the following way: If $V_{t}$ is the market value of a firm's shares, then following King (1974), the net-of-tax yield from investing $V_{t}$ at the market rate of interest must equal the net-of-tax dividends, $D_{t}$, plus the capital gain in order to achieve equilibrium in the capital market

$$
i_{t}\left(1-m_{t}^{i}\right) V_{t}=\frac{1-m_{t}^{d}}{1-c_{t}} D_{t}+\left(1-z_{t}\right)\left(V_{t+1}-V_{t}-N_{t}\right)
$$

where $i_{t}$ is the market rate of interest at time $t, m_{t}^{i}$ is the personal tax rate on interest income, $m_{t}^{d}$ is the tax rate on dividend income, $z_{t}$ is the capital gains' tax rate, $c_{t}$ is the rate of tax credit on dividends, and $N_{t}$ is the new equity issued.

Solving this difference equation and assuming a one unit increase in the capital stock 
in period $t d K_{t}=1$, which is reduced in the next period so that $d K_{k}=0 \forall k \neq t$, yields a change in the value of the firm $R=d V_{t}=\sum_{k=0}^{\infty}\left[\frac{\theta d D_{t+k}-d N_{t+k}}{(1+\rho)^{k}}\right]$, where $\theta=$ $\left(1-m_{t}^{d}\right) /\left(1-c_{t}\right)\left(1-z_{t}\right)$ and $\rho=\left(1-m_{t}^{i}\right) i_{t} /\left(1-z_{t}\right)$.

From the equation for the appropriation of income, one obtains $D_{t}$ as $D_{t}=Y\left(K_{t-1}\right)(1-$ $\left.\tau_{t}^{s}\right)-I_{t}+B_{t}-\left(1+i_{t}\left(1-\tau_{t}^{s}\right)\right) B_{t-1}+\tau_{t}^{s} \phi_{t}\left(I+K_{t-1}^{T}\right)+N_{t}$. Output Y in period t is a function of the beginning of year capital stock $K_{t-1}, \tau_{t}^{s}$ is the statutory corporate tax rate, $I_{t}$ is investment, $B_{t}$ is debt, with interest payments assumed to be tax-deductible, $\phi_{t}$ is the depreciation rate of capital, and $K_{t-1}^{T}$ is defined as tax-written-down value of capital stock at the beginning of $t$ (Devereux and Griffith, 2003). Deriving the change in $d D_{t+k}$ from the equation for $D_{t}$ and plugging into the equation for $d V_{t}$, Devereux and Griffith (2003) obtain $R$ and subsequently the EATR for different sources of financing.

Throughout this paper I assume that $\theta=1$, i.e., $m_{t}^{d}=c_{t}=z_{t}=0$. Additionally, I assume that $m_{t}^{i}=0$, which leads to the nominal discount rate of shareholders $\rho=i$. $\theta$ was first defined by King (1974) as a measure of the degree of discrimination between retaining profits and distributing profits as dividends. In other words, if paying dividends generates more tax liability as compared to retaining earnings, then $\theta<1$. Therefore, assuming that $\theta=1$, or equivalently not considering personal income taxes, implies that financing projects either by retained earnings, or the issue of new shares yields the same EATR.

Based on the assumptions above,

$$
R=\frac{1}{1+i}\left[(p+\delta)(1+\pi)\left(1-\tau^{s}\right)-((1+i)-(1-\delta)(1+\pi))(1-A)\right]+F
$$

where the first term in brackets is the net-of-tax change in output caused by a one unit increase in the capital stock, with $p$ being the real financial return, $\delta$ one period cost of depreciation and $\pi$ the inflation rate, which is the same for capital and output. The second term in brackets is the required decrease in investment to keep capital stock unchanged in period $t+1$. $A$ is the NPV of tax allowances per unit of investment and $F$ is the cost of raising external finance. ${ }^{9}$

Provided that the investment is financed by debt, because of deductible interest payments, taxable income will be lower, and hence the EATR is smaller. To see this, note that if the firm borrows $1-\phi \tau$ in period $t$, then $R$ incorporates the amount of deductible interest payments $F=i \tau^{s} \frac{1-\phi \tau^{s}}{1+i}$, which leads to a lower EATR as compared

\footnotetext{
${ }^{9}$ For $\theta=1$ and $\rho=i, A=\phi \tau^{s} \frac{(1+i)}{i}\left(1-\frac{1}{(1+i)^{T+1}}\right)$, where $T=1 / \phi$ for straight-line depreciation, and $A=\phi \tau^{s} \frac{(1+i)}{(i+\phi)}$ for declining balance. See also Da Rin et al. (2011).
} 
to the case when $F=0$, which is equivalent to financing by retained earnings or equity. ${ }^{10}$

Correspondingly, $R^{*}$ is simply $R$ without the taxes, or

$$
R^{*}=-1+\frac{1}{1+i}[(p+\delta)(1+\pi)+(1-\delta)(1+\pi)]=\frac{p-r}{1+r}
$$

using the relationship between the real $r$ and nominal $i$ interest rates $(1+r)(1+\pi)=$ $(1+i)$. The difference $R^{*}-R$ is then scaled by the NPV of the pre-tax total income stream net of depreciation $p /(1+r)$ in order to obtain a measure of the EATR (See Appendix A.3).

Similarly to Da Rin et al. (2011), I measure the nominal interest rate $i$ with the rate of short-term government bonds. In particular, two-year government bond rates are used for Bulgaria, Poland and Slovakia, and one-year government bond and one year treasury bill rates for the Czech Republic and Hungary, respectively. No such rate is available for Romania, so it is approximated with the money market interested rate, taken from Eurostat. I use the Harmonized Indices of Consumer Prices from Eurostat as a measure of the inflation rate $\pi$.

The maximum depreciation rates for plant and machinery in the cases of Poland and Hungary, heavy machinery for the Czech Republic and Slovakia, and machines and manufacturing equipment for Bulgaria and Romania are used as the rates at which capital expenditure is offset against tax $\phi$. The results presented below are robust to using other asset categories' depreciation rates and the average of these.

The financial rate of return $p$ is obtained by subtracting expenditures on employees (staf) from the added value ( $a v)$, and dividing this difference by the added value: (avstaf)/av, where in AMADEUS av is defined as the sum of taxes paid (taxa), profit/loss for the period ( $p l)$, depreciation (depre), interest paid (inte), and labour expenses (staf). Da Rin et al. (2011) employ an identical measure but on an industry level.

A major problem is that about $90 \%$ of the AMADEUS firms have missing values for interest paid. For this reason, $p$ is calculated without including this variable. However, estimates are presented for the small sample of firms who have reported interest payments, with $p$ calculated accordingly, with the results confirming income shifting, although the non-transitory responses tend to be lower (close to zero) than the long-term responses estimated without inte.

All remaining variables, namely $r, A, R$ and $R^{*}$ are calculated using the formulas described above. The one-period cost of depreciation $\delta$ is assumed to take a value of $12.5 \%$, taken from Da Rin et al. (2011). A step-by-step explanation of the variables and

\footnotetext{
${ }^{10}$ The assumption is that the firm is eligible for an immediate tax allowance of $\phi \tau^{s}$, hence $1-\phi \tau^{s}$.
} 
formulas used to calculate the EATR is provided in Appendix A.3.

\subsection{Taxable income}

In general, the measure of firms' taxable income, which is taxes paid divided by the statutory tax rate, is only an approximation of the true taxable income, given the limitations of the data. In particular, there is no information on incurred losses, which can be carried forward for 5 consecutive years in all countries and are in effect a deferred tax, since they appear as deductions in future periods (Hanlon, 2003). This means that a lot of firms will report zero TI in year $t$, because of previous year losses, even if they are profitable at time $t$.

Table 4 provides descriptive statistics for all variables of interest. TI is between $5 \%$ and $10 \%$ of total assets, with the notable exception of 2001 , when the ratio is 0.5 . This high ratio is due to the large number of Romanian microenterprises subject to $1.5 \%$ tax in 2001, which lowers the mean of the tax rates in that year substantially, while raising the ratio of TI to Toas considerably as microenterprises' tax base is turnover. If the data is weighted by turnover, the weighted mean of $\frac{T I}{T o a s}$ for 2001 is .079. The same occurs with inflation whose mean is well above the weighted mean due to the very large number of Romanian firms relative to the remaining sample.

Table 4 further shows the three corporate tax rates of interest: the statutory, and the effective tax rates assuming the project is financed by equity $\left(\tau^{e e}\right)$, and debt $\left(\tau^{e d}\right)$, respectively. $\tau^{e e}$ closely follows the statutory tax rate and is very similar in value, while $\tau^{e d}$ is much lower. Figures 4 and 5 show the distributions of $\tau^{e e}$ and $\tau^{e d}$, respectively, in the range $(0,1)$ for the period 1999-2005. Compared to $\tau^{e e}, \tau^{e d}$ 's distribution is more compressed, with a lower mean and less rate variability.

Both tax rates, however, are lower than they should be, since interest payments were not included in the calculation of the rate of return, which resulted in smaller $p$, and hence lower effective tax rates. In Table 4, the tax rates' means are for firms that have realised some profit, i.e., the rates are in the range $(0,1)$. In the subsequent estimation I use tax rates in the range $(-0.01,1)$ in order to reduce the influence of very negative values of the effective tax rates. ${ }^{11}$

\footnotetext{
${ }^{11}$ Given the formulas for the effective tax rates, I obtain a number of firms which face tax rates greater than $100 \%$ and some facing negative tax rates (subsidy). The firm-year observations with tax greater than $100 \%$ are 1,930 for $\tau^{e e}\left(3,337\right.$ for $\left.\tau^{e d}\right)$, all of which drop out from the subsequent estimation as $\ln (1-\tau)$ becomes negative, and therefore not defined. $75.8 \%(70.5 \%)$ of these are Romanian enterprises that experienced very high inflation in the period 1999-2003. Inflation in Romania began to normalise in 2005 , declining to $9 \%$. The firm-year observations with a negative tax rate are $25,640\left(115,440\right.$ for $\left.\tau^{\text {ed }}\right)$; the estimation includes businesses facing tax rates in the negative range $(-0.01,0)$, or $20,805(29,014)$ firm-year observations, leaving out $4,835(86,426)$ firm-year observations with tax rates smaller than
} 
Table 4: DESCRIPTIVE STATISTICS

\begin{tabular}{|c|c|c|c|c|c|c|c|}
\hline & $\begin{array}{c}1999 \\
\text { Mean }\end{array}$ & $\begin{array}{c}2000 \\
\text { Mean }\end{array}$ & $\begin{array}{c}2001 \\
\text { Mean }\end{array}$ & $\begin{array}{c}2002 \\
\text { Mean }\end{array}$ & $\begin{array}{c}2003 \\
\text { Mean }\end{array}$ & $\begin{array}{c}2004 \\
\text { Mean }\end{array}$ & $\begin{array}{r}2005 \\
\text { Mean }\end{array}$ \\
\hline$\frac{T I_{t}}{\text { Toast }}$ & $\begin{array}{c}.093 \\
(.175)\end{array}$ & $\begin{array}{c}.110 \\
(.201)\end{array}$ & $\begin{array}{c}.493 \\
(.792)\end{array}$ & $\begin{array}{c}.065 \\
(.232)\end{array}$ & $\begin{array}{c}.053 \\
(.136)\end{array}$ & $\begin{array}{c}.057 \\
(.155)\end{array}$ & $\begin{array}{c}.076 \\
(.186)\end{array}$ \\
\hline$\tau^{s}$ & $\begin{array}{c}.328 \\
(.077)\end{array}$ & $\begin{array}{c}.238 \\
(.032)\end{array}$ & $\begin{array}{c}.136 \\
(.116)\end{array}$ & $\begin{array}{c}.232 \\
(.064)\end{array}$ & $\begin{array}{c}.251 \\
(.035)\end{array}$ & $\begin{array}{c}.218 \\
(.040)\end{array}$ & $\begin{array}{l}.171 \\
(.030)\end{array}$ \\
\hline$\tau^{e e}$ & $\begin{array}{c}.342 \\
(.125)\end{array}$ & $\begin{array}{c}.280 \\
(.085)\end{array}$ & $\begin{array}{c}.150 \\
(.136)\end{array}$ & $\begin{array}{c}.242 \\
(.087)\end{array}$ & $\begin{array}{c}.245 \\
(.064)\end{array}$ & $\begin{array}{c}.197 \\
(.073)\end{array}$ & $\begin{array}{c}.172 \\
(.044)\end{array}$ \\
\hline$\tau^{e d}$ & $\begin{array}{c}.147 \\
(.094)\end{array}$ & $\begin{array}{l}.163 \\
(.070)\end{array}$ & $\begin{array}{c}.102 \\
(.103)\end{array}$ & $\begin{array}{l}.171 \\
(.083)\end{array}$ & $\begin{array}{c}.191 \\
(.078)\end{array}$ & $\begin{array}{l}.151 \\
(.077)\end{array}$ & $\begin{array}{l}.148 \\
(.044)\end{array}$ \\
\hline $\ln$ (Cuas/Toas) & $\begin{array}{l}-.637 \\
(.726)\end{array}$ & $\begin{array}{l}-.588 \\
(.715)\end{array}$ & $\begin{array}{l}-.589 \\
(.715)\end{array}$ & $\begin{array}{l}-.554 \\
(.719)\end{array}$ & $\begin{array}{l}-.553 \\
(.743)\end{array}$ & $\begin{array}{l}-.575 \\
(.774)\end{array}$ & $\begin{array}{l}-.575 \\
(.779)\end{array}$ \\
\hline $\ln ($ Culi/Toas $)$ & $\begin{array}{c}-.685 \\
(1.02)\end{array}$ & $\begin{array}{c}-.681 \\
(.1 .06)\end{array}$ & $\begin{array}{c}-.525 \\
(1.01)\end{array}$ & $\begin{array}{l}-.507 \\
(1.06)\end{array}$ & $\begin{array}{c}-.579 \\
(1.13)\end{array}$ & $\begin{array}{c}-.765 \\
(1.22)\end{array}$ & $\begin{array}{c}-.780 \\
(1.25)\end{array}$ \\
\hline $\ln$ (Depre/Toas) & $\begin{array}{l}-3.41 \\
(1.27)\end{array}$ & $\begin{array}{l}-3.38 \\
(1.26)\end{array}$ & $\begin{array}{l}-3.53 \\
(1.28)\end{array}$ & $\begin{array}{l}-3.54 \\
(1.34)\end{array}$ & $\begin{array}{c}-3.57 \\
(1.4)\end{array}$ & $\begin{array}{c}-3.46 \\
(1.4)\end{array}$ & $\begin{array}{l}-3.42 \\
(1.41)\end{array}$ \\
\hline $\ln ($ Fias $/$ Toas $)$ & $\begin{array}{l}-1.37 \\
(1.15)\end{array}$ & $\begin{array}{l}-1.46 \\
(1.21)\end{array}$ & $\begin{array}{l}-1.48 \\
(1.25)\end{array}$ & $\begin{array}{l}-1.56 \\
(1.31)\end{array}$ & $\begin{array}{l}-1.60 \\
(1.35)\end{array}$ & $\begin{array}{l}-1.59 \\
(1.39)\end{array}$ & $\begin{array}{c}-1.58 \\
(1.4)\end{array}$ \\
\hline $\ln$ (Opre/Toas) & $\begin{array}{c}.834 \\
(1.13)\end{array}$ & $\begin{array}{c}.745 \\
(1.16)\end{array}$ & $\begin{array}{c}.688 \\
(1.08)\end{array}$ & $\begin{array}{c}.717 \\
(1.10)\end{array}$ & $\begin{array}{c}.624 \\
(1.09)\end{array}$ & $\begin{array}{c}.488 \\
(1.16)\end{array}$ & $\begin{array}{c}.414 \\
(1.17)\end{array}$ \\
\hline $\ln$ (Toas) & $\begin{array}{c}3.36 \\
(2.41)\end{array}$ & $\begin{array}{c}3.35 \\
(2.39)\end{array}$ & $\begin{array}{c}3.59 \\
(2.53)\end{array}$ & $\begin{array}{c}3.65 \\
(2.55)\end{array}$ & $\begin{array}{c}3.86 \\
(2.48)\end{array}$ & $\begin{array}{c}4.20 \\
(2.30)\end{array}$ & $\begin{array}{c}4.14 \\
(2.23)\end{array}$ \\
\hline$i$ & $\begin{array}{c}.485 \\
(.269)\end{array}$ & $\begin{array}{c}.289 \\
(.156)\end{array}$ & $\begin{array}{c}.299 \\
(.132)\end{array}$ & $\begin{array}{c}.185 \\
(.075)\end{array}$ & $\begin{array}{c}.141 \\
(.061)\end{array}$ & $\begin{array}{c}.140 \\
(.060)\end{array}$ & $\begin{array}{c}.059 \\
(.011)\end{array}$ \\
\hline$\phi$ & $\begin{array}{l}.147 \\
(.019)\end{array}$ & $\begin{array}{l}.148 \\
(.019)\end{array}$ & $\begin{array}{l}.149 \\
(.022)\end{array}$ & $\begin{array}{l}.146 \\
(.019)\end{array}$ & $\begin{array}{l}.150 \\
(.037)\end{array}$ & $\begin{array}{l}.148 \\
(.031)\end{array}$ & $\begin{array}{l}.149 \\
(.030)\end{array}$ \\
\hline$\pi$ & $\begin{array}{c}.322 \\
(.185)\end{array}$ & $\begin{array}{c}.313 \\
(.176)\end{array}$ & $\begin{array}{c}.271 \\
(.122)\end{array}$ & $\begin{array}{c}.170 \\
(.086)\end{array}$ & $\begin{array}{c}.114 \\
(.062)\end{array}$ & $\begin{array}{c}.091 \\
(.033)\end{array}$ & $\begin{array}{c}.067 \\
(.029)\end{array}$ \\
\hline$p$ & $\begin{array}{c}.438 \\
(.262)\end{array}$ & $\begin{array}{c}.468 \\
(.269)\end{array}$ & $\begin{array}{c}.463 \\
(.271)\end{array}$ & $\begin{array}{c}.498 \\
(.276)\end{array}$ & $\begin{array}{l}.530 \\
(.290)\end{array}$ & $\begin{array}{c}.518 \\
(.281)\end{array}$ & $\begin{array}{c}.514 \\
(.279)\end{array}$ \\
\hline $\mathrm{N}$ & 166,411 & 201,182 & 183,122 & 196,703 & 260,943 & 391,654 & 414,909 \\
\hline $\mathrm{TI}>0$ & 100,039 & 125,625 & 146,546 & 78,059 & 109,583 & 173,950 & 199,553 \\
\hline
\end{tabular}

Note: $\frac{T I_{t}}{\text { Toas }_{t}}$ is taxable income scaled by total assets; $\tau^{s}$ is the statutory tax rate; $\tau^{e e}$ is the effective tax rate assuming new investment is financed by equity (retained earnings); $\tau^{\text {ed }}$ is the effective tax rate assuming new investment is financed by debt only. The means of the tax rates are in the range $(0,1)$, i.e., they reflect the mean rates for firms with positive TI. See Footnote 11 in the text. $\ln$ (Cuas/Toas) is the natural log of the ratio between current assets (stocks + accounts receivable + other current assets) and total assets; $\ln$ (Culi/Toas) is the natural $\log$ of the ratio between current liabilities (loans + accounts payable + other current liabilities) and total assets; $\ln$ (Depre/Toas) is the natural $\log$ of the ratio of depreciation to total assets; $\ln$ (Fias/Toas) is the natural log of the ratio between fixed assets (tangible fixed assets + intangible fixed assets + other fixed assets, including financial fixed assets) and total assets; $\ln$ (Opre/Toas) is the natural log of the ratio between operating revenue and total assets; $\ln$ (Toas) is the natural-log of total assets. $i$ is the nominal interest rate, $\phi$ is the rate of depreciation for plant and machinery, $\pi$ is inflation, and $p$ is the rate of return. See also Appendix A.3. 
Figure $\square:$ ( ) ) ( \&7,9 ( AVERAGE CORPORATE TAX RATES, EQUITY: 1999-2005

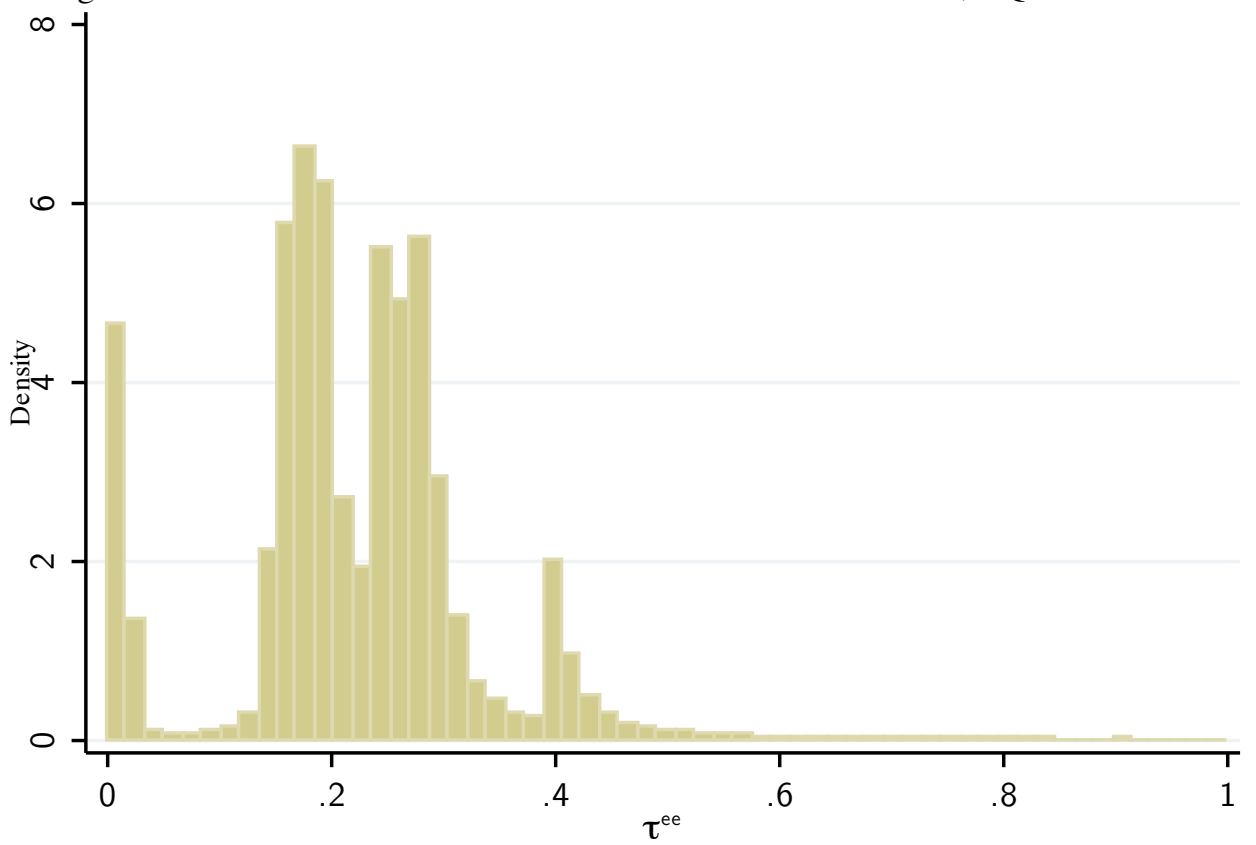

Figure [: EFFECTIVE AVERAGE CORORATE TAX RATES, DEBT: 1999-2005

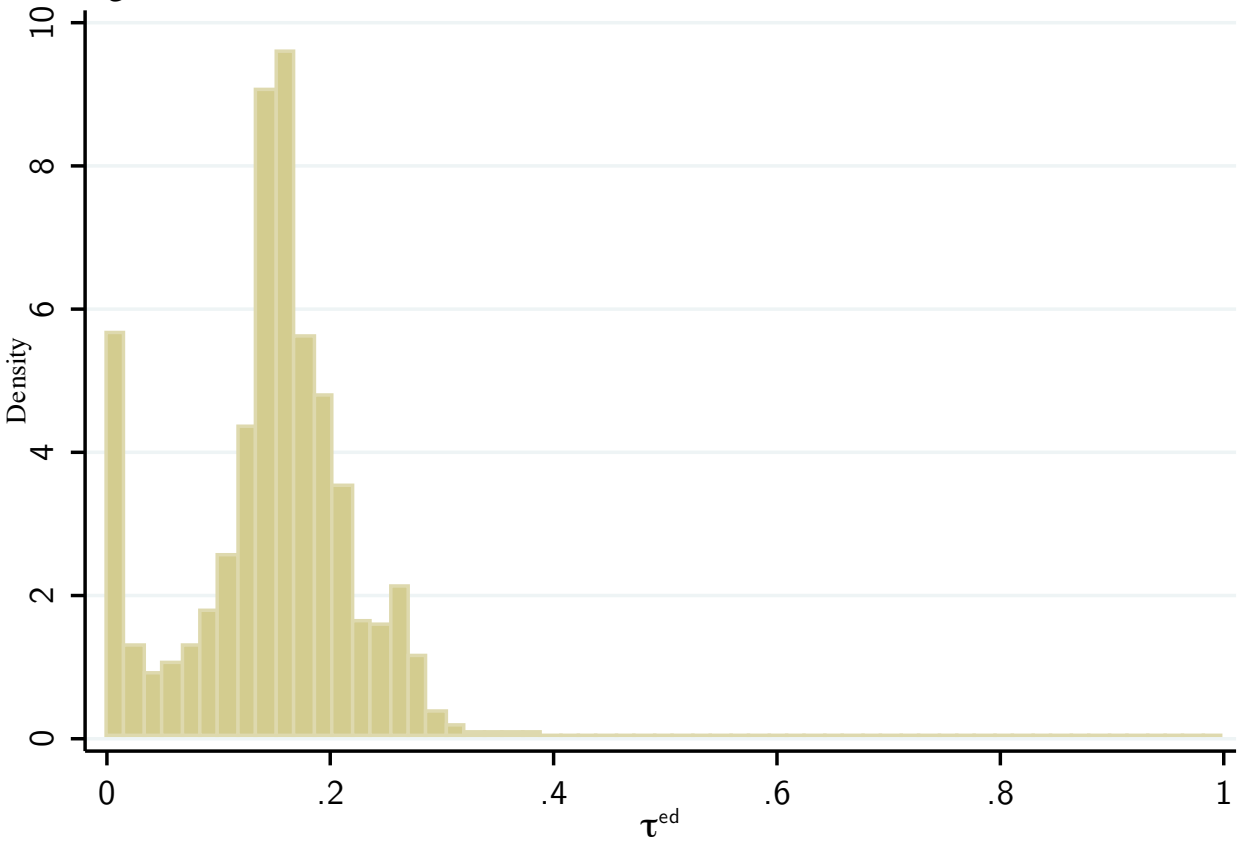


Unlike Western European countries, where the average inflation for the period 19992005 was about 3\%, CEE had high rates of inflation, especially in the period 1999-2002, which normalised to about $7 \%$, on average, in 2005 . The nominal interest rates reflect the high inflation rates and also decrease over time.

\subsection{Methodology}

The goal is to separate the long-run and short-run responses of taxable income to changes in the tax rates and this involves taking account of income shifting by firms in anticipation of lower future rates. To separate the responses, I employ the following specification:

$$
\begin{aligned}
\frac{T I_{i t}}{\text { Toas }_{i t}} & =\alpha_{i}+\beta_{1}\left[\ln \left(1-\tau_{i t}^{e}\right)-\ln \left(1-\tau_{i t-1}^{e}\right)\right]+\beta_{2} \ln \left(1-\tau_{i t}^{e}\right) \\
& +\beta_{3}\left[\ln \left(1-\tau_{i t+1}^{e}\right)-\ln \left(1-\tau_{i t}^{e}\right)\right]+\epsilon_{i t} \\
& =\alpha_{i}+\left(\beta_{1}+\beta_{2}-\beta_{3}\right) \ln \left(1-\tau_{i t}^{e}\right)-\beta_{1} \ln \left(1-\tau_{i t-1}\right)+\beta_{3} \ln \left(1-\tau_{i t+1}\right)+\epsilon_{i t}
\end{aligned}
$$

which is similar to the one used by Heim (2006) and Goolsbee (2000). $T I_{i t}$ is the taxable income of firm $i$ in year $t$ scaled by total assets Toas. $\ln \left(1-\tau_{i t-1}^{e}\right), \ln \left(1-\tau_{i t}^{e}\right)$, and $\ln \left(1-\tau_{i t+1}^{e}\right)$ are the natural logarithms of the lagged, the contemporaneous, and the leading net-of-EATR shares, respectively, and $\alpha_{i}$ are firm fixed effects. $\alpha_{i}$ capture unobserved heterogeneity for firm $i$, assuming that firms differ randomly in a way that is not completely controlled for by the observed covariates (Cameron and Trivedi, 2009a). In this specification, $\frac{T I}{T \text { Toas }}$ in period $t$ is affected not only by the current tax rate, but also by the difference between the current and lagged and current and leading rates.

If $\tau_{t-1}^{e}>\tau_{t}^{e}>\tau_{t+1}^{e}$, I expect firms to shift income out of year $t-1$ into the current year $t$, and again, out of year $t$ into $t+1$. Let $\tau_{t-1}^{e}-\tau_{t}^{e}=\Delta \tau^{e}$. Then deferring $\$ 1$ of $T I$ to year $t$ translates into gaining $\frac{\Delta \tau^{e}}{1-\tau_{t-1}^{e}}$. Thus, the effect of $\ln \left(1-\tau_{i t-1}^{e}\right)$ on taxable income in the current year, $T I_{t}$, is likely to be positive $\left(\beta_{1}>0\right)$, and that of $\ln \left(1-\tau_{i t+1}^{e}\right)$ - negative $\left(\beta_{3}<0\right)$. The coefficient of the current net-of-tax share is a combination of the current effect and two shifting coefficients, which entails the explicit control for the

$-1 \%$. It is worth pointing out that more than $60 \%$ of all firms with negative tax rates belong to a narrow category of firms, which are also the most difficult to tax, namely: General construction and plumbing; restaurants and bars; sale, maintenance and repair of motor vehicles; sales agents; and retail trade with food, beverages and tobacco predominant. Last but not least, the firm-year observations facing a zero effective tax rate are 862,694 for both $\tau^{e e}$ and $\tau^{e d}$, or approximately $47 \%$ of the whole sample. Again, more than $63 \%$ of the firms with zero effective tax rates belong to NACE2: 45, 50, 51, 52, and 55, i.e., construction, wholesale and retail trade and hotels and restaurants, and to NACE2 74, which is accounting and tax consulting services. 
lagged and leading shares, if $\beta_{2}=\left(\beta_{1}+\beta_{2}-\beta_{3}\right)-\beta_{1}+\beta_{3}$, the long-run effect, is to be estimated consistently.

In the linear-log specification, the coefficients measure the absolute change in $\frac{T I_{i t}}{\text { Toas }_{i t}}$ for a relative change in the net-of-tax shares, so that a $1 \%$ increase in $\ln \left(1-\tau_{i t+1}\right)$, increases the ratio of TI to total assets by $\beta_{3} / 100$, where the division comes from the switch from relative to percentage change. The reason why I cannot log-transform the dependent variable is that such transformation turns observations with zero taxable income into missing values, thus creating gaps in the individual firm-panels as $\log (0)$ is not defined.

If I log-transform, the estimation will be based solely on firms that have reported positive taxable incomes. Therefore, the dependent variable is no longer $E[\ln (T I)]$ but $E[\ln (T I) \mid x, T I>0]$. Without the log-transformation, there is a mass point of TI at zero, but not a problem with observability of the dependent variable. In other words, the zeros in the case of firms' taxable income are not due to self-selection but are an actual outcome value. For this reason self-selection models are not appropriate for the data, while if Tobit is used, I need to assume random effects and even then, differencing the data to eliminate the firm-effects can lead to complications. ${ }^{12}$

There are several problems with the specification as presented above. First, $\ln \left(1-\tau_{i t}^{e}\right)$ is endogenous in (5) not only due to spurious correlation stemming from the fact that common factors, such as taxes paid taxa and the statutory tax rate $\tau^{s}$, determine both $T I_{i t}$ and the effective tax rate $\tau_{i t}^{e}$, but also due to reverse causality. For example, in the case of firms that sustain losses, it is TI that determines the tax rate. Similarly, smaller firms can be taxed at preferential rates, provided that their TI do not exceed a certain limit.

Second, even if a suitable instrumental variable (IV) for $\ln \left(1-\tau_{i t}^{e}\right)$ is available, an additional problem arises due to the dynamic nature of the specification and the assumption that the fixed-effects $\alpha_{i}$ are correlated with the observed regressors $x_{i t}$, which necessitates $\alpha_{i}$ 's elimination through the transformation of the data. In particular, note that a fixed-effects, two-stage least square estimation of (5) will lead to an inconsistent first stage. The first stage is an OLS of the demeaned data:

$$
\begin{aligned}
\ln \left(1-\tau_{i t}^{e}\right)-\overline{\ln \left(1-\tau_{i}^{e}\right) .} & =\gamma_{0}+\gamma_{1}\left(I V_{i t}-\overline{I V_{i .}}\right)+\gamma_{2}\left[\ln \left(1-\tau_{i t-1}^{e}\right)-\overline{\ln \left(1-\tau_{i}^{e}\right)_{-1}}\right] \\
& +\gamma_{3}\left[\ln \left(1-\tau_{i t+1}^{e}\right)-\overline{\ln \left(1-\tau_{i}^{e}\right)_{+1}}\right]+\varepsilon_{i t}-\overline{\varepsilon_{i .}},
\end{aligned}
$$

\footnotetext{
${ }^{12}$ See Kalwij (2003) for more details on Tobit in first-differences with individual effects. Since taxable income is zero when a loss is realised, it is in fact a censored variable, so that: $T I_{i t}=T I_{i t}^{*}$ if $T I_{i t}^{*}>0$ (taxable profit is realised) and $T I_{i t}=0$ if $T I_{i t}^{*} \leq 0$ (taxable loss or the firm breaks even).
} 
where $\overline{\ln \left(1-\tau_{i}^{e}\right)} .=T_{i}^{-1} \sum_{t=1}^{t=T_{i}} \ln \left(1-\tau_{i t}\right), \overline{\ln \left(1-\tau_{i}^{e}\right)_{-1}}=T_{i}^{-1} \sum_{t=0}^{t=T_{i}-1} \ln \left(1-\tau_{i t}\right)$, and $\overline{\ln \left(1-\tau_{i}^{e}\right)_{+1}}=T_{i}^{-1} \sum_{t=2}^{t=T_{i}+1} \ln \left(1-\tau_{i t}\right)$. This regression would lead to inconsistent parameter estimates, because $\ln \left(1-\tau_{i t-1}^{e}\right)$ and $-T_{i}^{-1} \ln \left(1-\tau_{i t}^{e}\right)$ are correlated with $-T_{i}^{-1} \varepsilon_{i t-1}$ and $\varepsilon_{i t}$, respectively. Similar negative correlations occur for the leading net-oftax share, yielding an inconsistent within estimator (Bond, 2002). For a single lagged dependent variable, Nickell (1981) demonstrates that the leading negative correlations outweigh the positive correlations between terms such as $-T_{i}^{-1} \varepsilon_{i t-1}$ and $-T_{i}^{-1} \ln \left(1-\tau_{i t-1}\right)$, resulting in downward bias in $\gamma_{2}$. Eq.(6), however, contains a second endogenous variable, making it unclear if the bias formulas hold in this case. In fact, an IV estimation in the presence of any lagged or leading terms in levels will produce an inconsistent withinestimator (Cameron and Trivedi, 2009b). Therefore, in order to remove $\alpha_{i}$ and estimate eq.(6), and therefore eq.(5) consistently, I turn to the first-difference estimator.

An important advantage of the first-differencing transformation is that, unlike demeaning, it does not introduce all realisations of the disturbances $\left(\varepsilon_{i 1}, \varepsilon_{i 2}, \ldots \varepsilon_{i T}\right)$ into the transformed error term. Nevertheless, adjacent time periods are still problematic. Note that in the first-differenced first stage of (5)

$$
\ln \left(\frac{1-\tau_{i t+1}^{e}}{1-\tau_{i t}^{e}}\right)=\theta_{0}+\theta_{1} \triangle I V_{i t+1}+\theta_{2} \ln \left(\frac{1-\tau_{i t}^{e}}{1-\tau_{i t-1}^{e}}\right)+\theta_{3} \ln \left(\frac{1-\tau_{i t+2}^{e}}{1-\tau_{i t+1}^{e}}\right)+\triangle \varepsilon_{i t+1},
$$

$\triangle \varepsilon_{i t+1}$ is correlated with $\ln \left(\frac{1-\tau_{i t}^{e}}{1-\tau_{i t-1}^{e}}\right)$ and $\left(\frac{1-\tau_{i+2}^{e}}{1-\tau_{i t+1}^{e}}\right)$, since $\ln \left(1-\tau_{i t}^{e}\right)$ and $-\ln (1-$ $\left.\tau_{i t+1}^{e}\right)$ are correlated with $-\varepsilon_{i t}$ and $\varepsilon_{i t+1}$, respectively, leading to a downward bias. It is uncertain how the bias in the case of first differencing will compare to demeaning considering the second endogenous regressor. $\ln \left(1-\tau_{i t-k}^{e}\right)$, for $k \geq 2$, however, is not correlated with the error term, which opens up the possibility for consistent estimation using a longer difference window. Specifically a two year window is considered, so that (5) becomes

$$
\begin{aligned}
\frac{T I_{i t+2}}{\text { Toas }_{i t+2}}-\frac{T I_{i t}}{\text { Toas }_{i t}} & =\lambda_{t}+\lambda_{j t}+\lambda_{c t}+\sigma_{1} \ln \left(\frac{1-\tau_{i t+2}^{e}}{1-\tau_{i t}^{e}}\right)-\sigma_{2} \ln \left(\frac{1-\tau_{i t+1}^{e}}{1-\tau_{i t-1}^{e}}\right) \\
& +\sigma_{3} \ln \left(\frac{1-\tau_{i t+3}^{e}}{1-\tau_{i t+1}^{e}}\right)+\triangle X^{\prime} \Gamma+\epsilon_{i t+2}-\epsilon_{i t}
\end{aligned}
$$

which will result in a consistent first stage of the 2SLS, provided that two key assumptions are met: $\varepsilon_{i t}$ are independent across firms and $\varepsilon_{i t}$ are serially uncorrelated.

$\lambda_{t}, \lambda_{j t}, \lambda_{c t}$ are year, industry-year (NACE2 level) and country-year dummies, respec- 
tively; $X$ includes the natural logarithm of the ratios of current assets, current liabilities, depreciation, fixed assets, and operating revenue to total assets as well as the natural log of total assets.

As explained above, eq.(8) requires an IV for the contemporaneous change in the netof-tax shares $\ln \left(\frac{1-\tau_{i t+2}^{e}}{1-\tau_{i t}^{e}}\right)$. Using Gruber and Rauh (2007)'s methodology, I construct an instrument by calculating the EATR in year $t+2$ with the firm characteristics from year $t$. Specifically, I keep the added value $a v$ at its year $t$ level and inflate it by the producer price index, but allow the macroeconomic variables, such as the statutory tax rate, depreciation rules, etc., to change. The idea is to make the change in the net-of-tax shares between year $t$ and $t+2$ exogenous to firm behaviour by removing that component of the change, which can be driven by tax planning considerations. The instrument for $\ln \left(\frac{1-\tau_{i t+2}^{e}}{1-\tau_{i t}^{e}}\right)$ is therefore $\ln \left(\frac{1-\tau_{i t+2}^{p}}{1-\tau_{i t}^{e}}\right)$, where $1-\tau_{i t+2}^{p}$ is the predicted net-of-tax share. All subsequent 2SLS regressions have strong first stages with F-statistics for the coefficient of the IV always above 1000.

One major disadvantage of using a two-year difference window is the possible underestimation of the short-term response, especially if firms are able to react to tax changes swiftly from year to year. Company size and the level of indebtedness may capture some of this flexibility in the model, but time is certainly a factor. In contrast, it is also probable that the highest responsiveness occurs a few years after a tax reform, in which case the specification in (8) is appropriate.

An indisputable drawback of the two-year window, however, is the big loss of firmyear observations. In addition, the inclusion of the lagged and leading terms require that a firm be present in the panel for at least 5 years, which deprives the estimation of valuable information from firms, appearing for fewer years. Moreover, the estimates should be taken as representing the shifting behaviour of already well-established firms rather than new entrants. It is for these reasons that I additionally present regressions in first-differences, despite the endogeneity discussed above, and compare the obtained results to the estimates using eq.(8).

It is worth noting that even if second-differencing removes part of the endogeneity in the estimation, it is still an imperfect method. In particular, the lack of data on loss carryforwards, which can be offset against future taxable income, means that past disturbances, usually over a five year period, will be correlated with the current net-oftax shares. In fact, firms' behaviour with respect to the use of taxable losses to shelter other forms of taxable income is unaccounted for. As observed by Mintz (1988), the difference in firms' ability to use write-offs leads to substantial variation in the effective 
tax rates, unrelated to changes in tax law or the statutory tax rates. Neither $\tau^{e e}$, or $\tau^{e d}$ incorporate this variation. It is also clear that a large number of firms may have utilised tax incentives not covered by the ones explicitly controlled for in this paper.

\section{Results}

\subsection{Effect of anticipated CIT rates on taxable income}

The main results are presented in Table 5. Firm fixed effects are eliminated through second-differencing in all specifications. The effective tax rate is calculated based on a rate of return, which does not include interest payments for reasons described above, and the assumption that the project is financed by equity. Column (1) shows the basic regression of the change in the ratio of taxable income to total assets on the change in the log of the current net-of-tax share, without other controls except a constant, which acts as a time trend and accounts for income-to-assets growth. The contemporaneous effect is estimated to be 0.208 , and given the specification, it should suffer from omitted variable bias. If the correlations between the current and lagged and the current and leading net-of-tax shares were positive, then this bias would be downward.

Column (2) allows for a lagged transitory component, which has a negative and statistically significant impact on the change of taxable income. Note the dramatic increase in the current tax effect due to mitigation of the omitted variable bias. This suggests that while the contemporaneous effect is close to one, part of it is due to a timing shift of income from previous years with higher CIT rates to the current year.

The leading net-of-tax share is added in Column (3) and shows how current TI reacts to anticipated changes in the corporate tax rate. Similarly to the lagged CIT, this term has a negative impact on reported income, indicating that firms act on expectations of lower taxes in the future by deferring the declaration of income, accelerating expenses, or by other means. Both the current and lagged tax terms grow as a consequence of the inclusion of future taxes.

The current effect in Column (3) is much higher than that of Columns (1) and (2) and is estimated for firms who have at least 5 years of data. As a consequence, compared to Column (1), the number of firms is more than cut in half in the specification including all three net-of-tax shares, revealing a major loss of observations due to second-differencing, but also the extent to which the panel is unbalanced. The non-transitory response, or the sum of the three coefficients, is approximately 0.28 and significant.

The inclusion of the year fixed effects in Column (4), which is equivalent to a diff-in- 


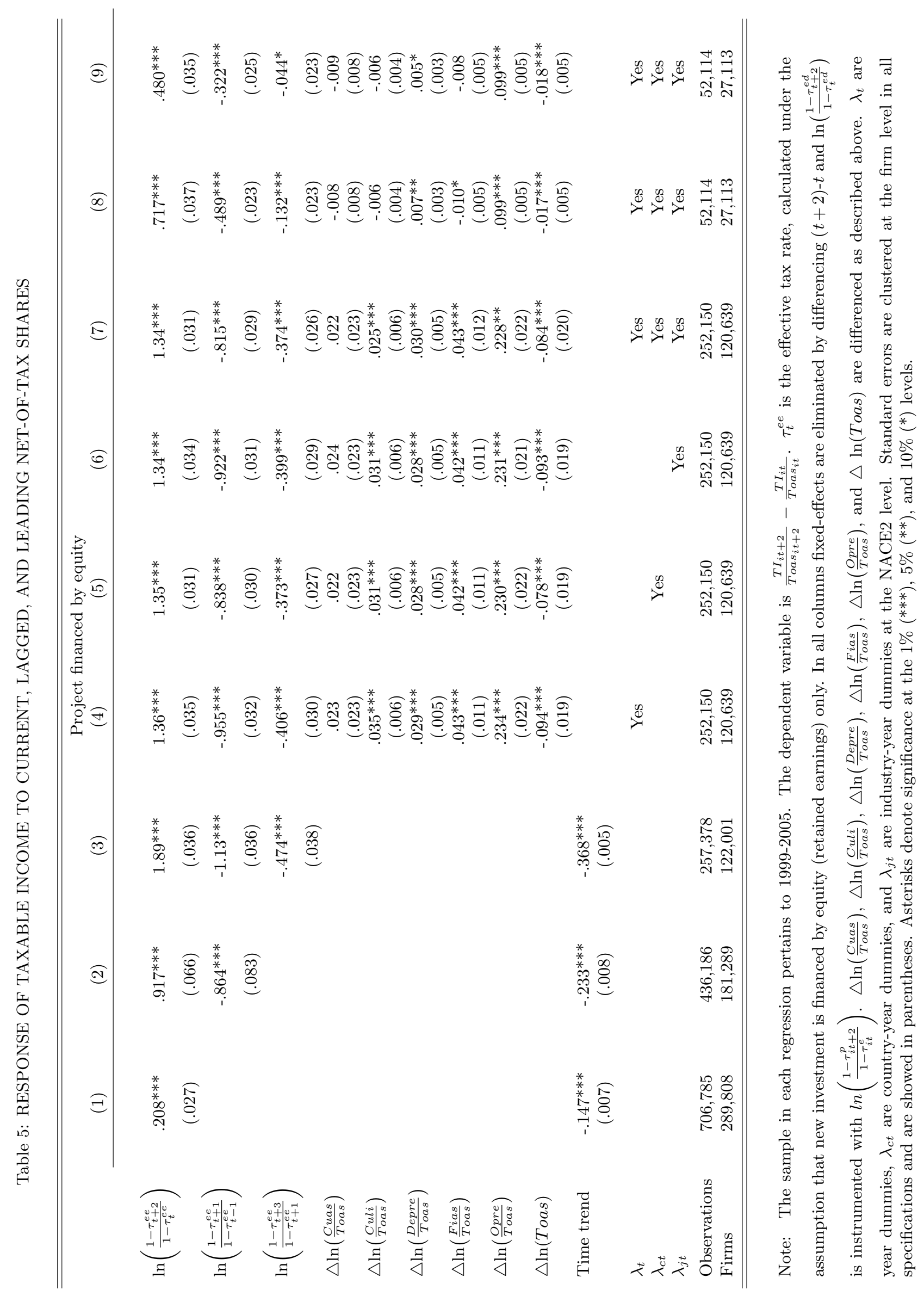


diff estimation, means that the response of taxable income is identified using solely the cross-sectional variation of the net-of-tax shares. Once other firm-level explanatory variables and year dummies are controlled for, both the current response and the shifting coefficients decrease, resulting in a long-term effect that is statistically not different from zero.

In particular, Column (4) accounts for the log-change in current assets (cuas), current liabilities (culi), depreciation (depre), fixed assets (fias), and operating revenue (opre), all scaled by total assets and the change in total assets themselves. An increase in cuas, opre, depre, fias, and culi raises the taxable income-total assets ratio, although the coefficient of cuas is not precisely estimated. By construction, an increase in Toas will decrease the $\frac{T I}{\text { Toas }}$ ratio. The positive sign of current liabilities seems counter-intuitive, but it may in fact reflect the possibility that highly indebted firms, which are close to violating debt covenants, may be unwilling to engage in aggressive tax planning. This is likely, given that debt covenants not only require the maintenance of certain financial health, but also determine how the numbers proving this financial health are calculated.

To purge the regression from country-specific shocks, Column (5) contains countryyear fixed effects. In this case the coefficients of interest are identified from the different timing and different size of the tax cuts and magnitude of other tax reforms across countries, yielding lower shifting coefficients in absolute value and thus, a positive and significant long-run response of .139.

Alternatively, Column (6) controls for shocks such as regulations and industry norms that affect different sectors differently by incorporating industry-year dummies at the NACE2 level. Similarly to the estimation with year dummies only, controlling for industry-year fixed effects leads to a permanent response that is not significantly different from zero.

Finally, year-, country-year and industry-year fixed effects are all allowed for in Column (7). This extensive dummy structure generates the largest significant non-transitory effect, .151, which nevertheless closely resembles the result in Column (5).

Utilising the richest specification, (8) repeats the regression in (7), but this time using an effective tax rate, which includes interest payments, i.e., the rate of return is comprised of all elements of added value. The number of firms falls drastically to about 27,000 . Although the coefficients of all three net-of-tax shares decrease substantially using this subsample of firms, income shifting is still present as signalled by the magnitude of the transitory components, while the long-run effect is almost identical to the one estimated in Column (7).

The influence of current liabilities is no longer significant, while that of fixed assets 
becomes negative. In view of the number of tax incentives and deductions available to new investment in CEE, the negative effect of fias is not unexpected, especially given that $66 \%$ of the 27,000 firms reporting interest payments are big and medium enterprises.

To check if it is the inclusion of interest payments in the calculation of $\tau^{e e}$ that drives the lower coefficients in (8) or the particular subsample of firms used, Column (9) reports results based on the same subsample, but using the baseline EATR, i.e. ones without inte. On account of the results in (9), it can be concluded that the lower estimated coefficients are subsample-specific.

\subsection{First-difference estimates}

Table 7 re-estimates some of the regressions from Table 5 in first-differences. To obtain coefficients on the leading and lagged net-of-tax shares, a firm should be present in the panel for at least four years, whereas a year of data is lost due to first-differencing. Nevertheless, about 54,000 firms that dropped out of the previous estimation as a consequence of employing a two-year window are re-incorporated. The trade-off, as explained in Section 4.4, is the inconsistency of the first stage estimation which spills over to the 2SLS coefficients, although, due to not controlling for loss carryforwards, some bias is bound to remain in second-differences as well.

The interesting problem here is that due to the presence of fixed effects and lagged and leading terms of an explanatory variable that is endogenous, the first stage of the 2SLS estimation suffers from the classic endogeneity inherent in dynamic panel data models. This endogeneity stems from the leading and lagged net-of-tax shares, both of which are exogenous in the original regression but become endogenous in the first stage and hence cannot act as their own instruments as they violate the exclusion restriction.

Even so, it is useful to compare the first-difference estimates to the results in Table 5, bearing in mind that apart from Column (1), the coefficients in Table 7 are inconsistent. The negative correlation of the leading and lagged net-of-tax shares with the error term in the first stage will lead to downward bias in their coefficients, although it is not clear how it will affect the coefficient of the instrument and thus the fitted value $I V{ }^{13}$ The predicted error from the first stage, which in general should be orthogonal to the righthand side of the second-stage regression, contains a bias term. The direction of bias of the 2SLS coefficients will therefore depend on the interaction between the conditional correlations and this bias term. ${ }^{14}$

\footnotetext{
${ }^{13}$ See Section 4.4 and the discussion under eq.(6) and (7).

${ }^{14} \mathrm{I}$ am thankful to Štěpán Jurajda for this comment.
} 
Table 6: FIRST STAGE COMPARISON: FIRST- VS. SECOND-DIFFERENCING

\begin{tabular}{lccc}
\hline \hline & First-difference & Second-difference \\
$\ln \left(\frac{1-\tau_{t+1}^{p}}{1-\tau_{t}^{e e}}\right)$ & $.813^{* * *}$ & $\ln \left(\frac{1-\tau_{t+2}^{p}}{1-\tau_{t}^{e e}}\right)$ & $.937^{* * *}$ \\
$\ln \left(\frac{1-\tau_{t}^{e e}}{1-\tau_{t-1}^{e e}}\right)$ & $(.014)$ & $\ln \left(\frac{1-\tau_{t+1}^{e e}}{1-\tau_{t-1}^{e e}}\right)$ & $.007)$ \\
$\ln \left(\frac{1-\tau_{t+2}^{e e}}{1-\tau_{t+1}^{e e}}\right)$ & $-.019^{* * *}$ & $\ln \left(\frac{1-\tau_{t+3}^{e e}}{1-\tau_{t+1}^{e e}}\right)$ & $(.0008)$ \\
& $(.001)$ & & $.003^{* *}$ \\
Observations & $-.046^{* * *}$ & & $(.001)$ \\
Firms & $(.003)$ & 252,150 \\
\hline \hline
\end{tabular}

Note: The sample in each regression pertains to $1999-2005$. The dependent variable is $\ln \left(\frac{1-\tau_{t+1}^{e e}}{1-\tau_{t}^{e e}}\right)$ in the first-difference estimation, and $\ln \left(\frac{1-\tau_{t+2}^{e e}}{1-\tau_{t}^{e e}}\right)$ in the second-difference estimation, with $\ln \left(\frac{1-\tau_{t+1}^{p}}{1-\tau_{t}^{e e}}\right)$, and $\ln \left(\frac{1-\tau_{t+2}^{p}}{1-\tau_{t}^{e e}}\right)$ being the respective instruments. All other balance-sheet explanatory variables from Table 5 are included but not reported. Country-year dummies, $\lambda_{c t}$, are also included. The relationship between the first-and second-differencing first stage coefficients remains robust to any dummy structure or lack thereof. Standard errors are clustered at the firm level in all specifications and are showed in parentheses. Asterisks denote significance at the $1 \%(* * *), 5 \%(* *)$, and $10 \%(*)$ levels.

Before looking at the first-difference estimates, Table 6 shows how the first stage changes when estimated in first- and second-differences. The results in Table 6 are obtained using country-year fixed effects, but no matter what the dummy structure is, the first-difference first stage estimates are always below the second-difference ones, suggesting a downward bias, as argued in the discussion of eq.(7).

In Column (1) of Table 7 the contemporaneous net-of-tax share is entered alone, which means that the first stage regression is consistent. Compared to the same estimate in Table 5, the coefficient in first-difference, .544, is almost three times as big as in second-differences, .208, suggesting that firms do not take as long as two years to respond to tax changes but react promptly. It is likely, therefore, that a two year window underestimates some of this responsiveness. Once the leading and lagged net-of-tax shares are incorporated in the subsequent columns, the current term is substantially lower than its second-difference equivalent, whereas the shifting coefficients become less negative, and in fact, the leading term turns positive. All in all, if firms are quicker to react across adjacent years than two years, these coefficients imply that the contemporaneous effect is biased downwards as opposed to the leading and lagged terms whose bias is possibly upward. 
Table 7: RESPONSE OF TAXABLE INCOME TO CURRENT, LAGGED, AND LEADING NET-OFTAX SHARES, FIRST-DIFFERENCE ESTIMATION

\begin{tabular}{|c|c|c|c|c|c|}
\hline & (1) & (2) & (3) & (4) & (5) \\
\hline $\ln \left(\frac{1-\tau_{t+1}^{e e}}{1-\tau_{t}^{e d}}\right)$ & $\begin{array}{c}.544^{* * *} \\
(.049)\end{array}$ & $\begin{array}{c}1.33^{* * *} \\
(.099)\end{array}$ & $\begin{array}{c}1.20^{* * *} \\
(.053)\end{array}$ & $\begin{array}{c}1.22^{* * *} \\
(.052)\end{array}$ & $\begin{array}{c}1.25^{* * *} \\
(.053)\end{array}$ \\
\hline $\ln \left(\frac{1-\tau_{t}^{e e}}{1-\tau_{t-1}^{e e}}\right)$ & & $\begin{array}{c}-.845^{* * *} \\
(.040)\end{array}$ & $\begin{array}{c}-.618^{* * *} \\
(.034)\end{array}$ & $\begin{array}{c}-.634^{* * *} \\
(.034)\end{array}$ & $\begin{array}{c}-.603^{* * *} \\
(.033)\end{array}$ \\
\hline $\ln \left(\frac{1-\tau_{t+2}^{e e}}{1-\tau_{t+1}^{e e}}\right)$ & & $\begin{array}{c}.615^{* * *} \\
(.047)\end{array}$ & $\begin{array}{c}.253^{* * *} \\
(.021)\end{array}$ & $\begin{array}{l}.144^{* * *} \\
(.020)\end{array}$ & $\begin{array}{c}.231^{* * *} \\
(.020)\end{array}$ \\
\hline $\begin{array}{l}\lambda_{t} \\
\lambda_{c t} \\
\lambda_{j t}\end{array}$ & & & Yes & Yes & Yes \\
\hline $\begin{array}{l}\text { Observations } \\
\text { Firms }\end{array}$ & $\begin{array}{c}1,071,593 \\
417,938\end{array}$ & $\begin{array}{l}408,278 \\
177,009\end{array}$ & $\begin{array}{l}399,286 \\
174,091\end{array}$ & $\begin{array}{l}399,286 \\
174,091\end{array}$ & $\begin{array}{l}399,286 \\
174,091\end{array}$ \\
\hline
\end{tabular}

Note: The sample in each regression pertains to 1999-2005. The dependent variable is $\frac{T I_{i t+1}}{\text { Toas }_{i t+1}}-\frac{T I_{i t}}{\text { Toas }_{i t}}$. $\tau_{t}^{e e}$ is the effective tax rate, calculated under the assumption that new investment is financed by equity (retained earnings) only. In all columns fixed-effects are eliminated by first-differencing $(t+1)-t$, and $\ln \left(\frac{1-\tau_{t+1}^{e e}}{1-\tau_{t}^{e e}}\right)$ is instrumented with $\ln \left(\frac{1-\tau_{t+1}^{p}}{1-\tau_{t}^{e e}}\right)$. All other balance-sheet explanatory variables from Table 5 are included in Columns (3)-(5) in first-differences and not reported here. $\lambda_{t}$ are year dummies, $\lambda_{c t}$ are country-year dummies, and $\lambda_{j t}$ are industry-year dummies at the NACE2 level. Standard errors are clustered at the firm level in all specifications and are showed in parentheses. Asterisks denote significance at the $1 \%(* * *), 5 \%(* *)$, and $10 \%(*)$ levels.

\subsection{Who shifts income?}

This section investigates in more detail what type of firms drive the non-transitory result, and in particular, whether the effect varies by firm size and ability to shift income. Large firms especially may be more sensitive to nontax costs of income deferral, but may also be more effective at shifting income as they have more sophisticated tax departments. Guenther (1994) and Scholes et al. (1992) describe two types of nontax costs: (1) those associated with income deferral such as costs caused by the acceleration of R\&D projects or dissatisfied customers if year-end shipments are delayed, and (2) political costs pertaining to meeting debt covenant restrictions and management compensation plans. Guenther (1994) concludes that larger firms will tend to reduce financial statement income if they defer taxable income to minimise cost in case they are subjected to public scrutiny. Scholes et al. (1992) estimates that large public firms are more tax opportunistic than small public companies and are more prone to shifting gross margin and selling, general and administrative expenses in expectation of tax cuts. 
Table 8: RESPONSE OF TAXABLE INCOME BY FIRM SIZE

\begin{tabular}{lccc}
\hline \hline & Small $(\mathrm{F})$ & Medium $(\mathrm{M})$ & Big $(\mathrm{T})$ \\
\cline { 2 - 4 } $\ln \left(\frac{1-\tau_{t+2}^{e e}}{1-\tau_{t}^{e d}}\right)$ & $1.71^{* * *}$ & $.227^{* * *}$ & $-.058^{* * *}$ \\
$\ln \left(\frac{1-\tau_{t+1}^{e e}}{1-\tau_{t-1}^{e e}}\right)$ & $(.042)$ & $(.031)$ & $(.009)$ \\
$\ln \left(\frac{1-\tau_{t+3}^{e e}}{1-\tau_{t+1}^{e e}}\right)$ & $-.879^{* * *}$ & $-.129^{* * *}$ & $-.028^{* * *}$ \\
& $(.040)$ & $(.011)$ & $(.004)$ \\
Observations & $-.537^{* * *}$ & -.005 & $-.011^{* *}$ \\
Firms & $(.033)$ & $(.012)$ & $(.005)$ \\
\hline \hline
\end{tabular}

Note: The sample in each regression pertains to 1999-2005. The dependent variable is $\frac{T I_{i t+2}}{T_{0 a s_{i t}+2}}-\frac{T I_{i t}}{\text { Toas }_{i t}}$. $\tau_{t}^{e e}$ is the effective tax rate, calculated under the assumption that new investment is financed by equity (retained earnings) only. In all columns fixed-effects are eliminated by differencing $(t+2)-t$ and $\ln \left(\frac{1-\tau_{t+2}^{e e}}{1-\tau_{t}^{e e}}\right)$ is instrumented. Firms were separated according to size in the following manner: $\operatorname{Big}(\mathrm{T})$ : operating revenue $\geq € 10$ million, total assets $\geq € 20$ million, number of employees $\geq 100$. Medium (M) companies: operating revenue $\geq € 1$ million, total assets $\geq € 2$ million, number of workers $\geq 15$. All columns include all other balance sheet explanatory variables used in Table 5 , as well as year, industry-year, and countryyear fixed effects not reported here. Standard errors are clustered at the firm level in all specifications and are showed in parentheses. Asterisks denote significance at the $1 \%(* * *), 5 \%(* *)$, and $10 \%\left({ }^{*}\right)$ levels.

In order to categorise firms into big, medium and small, I use AMADEUS's classification, based on total assets, operating revenue and number of employees. Firms with total assets greater or equal to $€ 20$ million, operating revenue of at least $€ 10$ million and no less than 100 employees belong to the Top 250,000 firms. Next are the Top 1,500,000 companies. In general, a firm should have total assets $\geq € 2$ million, operating revenue $\geq € 1$ million and at least 15 employees to qualify as a Top 1,500,000 company. Firms not belonging to the above two categories, are classified as small.

Table 8 splits the sample according to the size classification described above; $28 \%$ of firms belong to the Top 1,500,000 dataset, and 63\% are small firms. It is clear from Table 8 that the big contemporaneous and transitory coefficients estimated in Table 5 are mostly driven by small firms, which exhibit high anticipation to future rates. In fact, the long-term response for small firms is twice bigger than the highest response estimated in Table 5. The results are very different for medium and big companies, however.

$\ln \left(\frac{1-\tau_{t+2}^{e e}}{1-\tau_{t}^{e d}}\right)$ has a modest but significant impact on taxable income of medium-sized companies in the current year, and so does the lagged net-of-tax share, indicating that 
medium-sized firms undertake income shifting on a small scale. The leading effect, while negative, is insignificant. After accounting for income shifting, the non-transitory effect on TI for medium firms is much closer to the one obtained with the full sample.

When it comes to big firms, the current net-of-tax share has a negative and significant effect on taxable income, a contradictory result to the previous estimates. While both the lagged and leading change in tax rates have precisely estimated negative impact on TI, these effects are rather small. Big firms, therefore, do not seem to engage in aggressive intertemporal earnings management.

Considering bigger firms' access to many other tax management instruments, such as debt shifting, earnings distribution between subsidiaries, geographic income shifting, as well as investment tax incentives, it is probable that such firms find cheaper alternatives to the intertemporal shifting of income (Tang and Jog, 2001; Smart and Hong, 2010). This result is robust to splitting the sample by firms' number of managers, which can be used as a proxy for firm size. ${ }^{15}$

Another sample split, this time by country, is performed in Table 9 with the results varying greatly between countries. First, Bulgaria and Slovakia have negative estimated coefficients for the current effect, which are also statistically significant. An insignificant negative contemporaneous term is estimated for Hungary. Given that $75 \%$ of the total sample are Romanian firms, the coefficients for this county are closest to the full sample ones, as expected. Last but not least, Poland exhibits a modest current effect and small transitory coefficients, while in the case of the Czech Republic these effects are bigger, yet still well below the full sample estimates.

In a sense, however, Table 9 replicates the sample splits from Table 8, since 47,254 out of the 55,642 firm-year observations, or $84 \%$, for Bulgaria, the Czech Republic, Hungary, Poland and Slovakia are medium and big enterprises, for whom small positive and negative current net-of-tax share coefficients are estimated, respectively. It is, therefore, hard to consider the samples for these five countries representative, as most of the smaller firms simply do not appear in the panel for five consecutive years and drop out of the estimation. In the other extreme is Romania, with $74 \%$ small and $23 \%$ medium firms.

\footnotetext{
${ }^{15}$ In general I would expect that a firm's ability to shift income will increase proportionally to the number of managers it employs. Yet, this turns out not to be the case. The sample is divided into three subgroups: firms with zero to two managers, those with 2 up to 5 managers and firms employing more than 5 managers. The results are robust to using other subgroups and are almost identical to those in Table 8, with the most responsive firms being the ones with fewer managers, whereas companies with five or more managers have very small shifting coefficients. One possible explanation put forth by Guenther (1994) is that if management compensation is linked to firm performance, then executives may be reluctant to decrease taxable income to save taxes, even though this move would be beneficial to shareholders. Alternatively, as mentioned earlier, big firms can utilise a variety of tax instruments apart from income shifting, which are not easily procurable by smaller companies.
} 
Table 9: RESPONSE OF TAXABLE INCOME BY COUNTRY

\begin{tabular}{lcccccc}
\hline \hline & $\mathrm{BG}$ & $\mathrm{CZ}$ & $\mathrm{HU}$ & $\mathrm{PL}$ & $\mathrm{RO}$ & $\mathrm{SK}$ \\
\cline { 2 - 6 } $\ln \left(\frac{1-\tau_{t+2}^{e e}}{1-\tau_{t}^{e e}}\right)$ & $-.249^{* * *}$ & $.467^{* * *}$ & -.988 & $.169^{* * *}$ & $1.66^{* * *}$ & $-.108^{* * *}$ \\
$\ln \left(\frac{1-\tau_{t+1}^{e e}}{1-\tau_{t-1}^{e+}}\right)$ & $(.009)$ & $(.096)$ & $(.641)$ & $(.014)$ & $(.035)$ & $(.047)$ \\
& $-.020^{* *}$ & $-.295^{* *}$ & -.236 & $-.043^{* * *}$ & $-.928^{* * *}$ & -.022 \\
$\ln \left(\frac{1-\tau_{t+3}^{e e}}{1-\tau_{t+1}^{e e}}\right)$ & $(.006)$ & $(.135)$ & $(.144)$ & $(.009)$ & $(.033)$ & $(.017)$ \\
& $\left.-.011^{\text {ee }}\right)$ & $-.287^{* * *}$ & .386 & -.005 & $-.417^{* *}$ & .002 \\
Observations & $(.003)$ & $(.075)$ & $(.508)$ & $(.006)$ & $(.028)$ & $(.024)$ \\
Firms & 15,712 & 10,212 & 13,783 & 13,929 & 196,508 & 2,006 \\
\hline \hline
\end{tabular}

Note: The sample in each regression pertains to 1999-2005. The dependent variable is $\frac{T I_{i t+2}}{T_{o a s} i t+2}-\frac{T I_{i t}}{T_{o a s_{i t}}}$. $\tau_{t}^{e e}$ is the effective tax rate, calculated under the assumption that new investment is financed by equity (retained earnings) only. In all columns fixed-effects are eliminated by differencing $(t+2)-t$ and $\ln \left(\frac{1-\tau_{t+2}^{e e}}{1-\tau_{t}^{e e}}\right)$ is instrumented. The sample is split by country. All columns include all other balance sheet explanatory variables used in Table 5, as well as year and industry-year effects, not reported here. Standard errors are clustered at the firm level in all specifications and are showed in parentheses. Asterisks denote significance at the $1 \%(* * *), 5 \%(* *)$, and $10 \%(*)$ levels.

As a robustness check, Table 10 repeats the regressions from Table 5, using the effective tax rate $\tau^{e d}$, based on the assumption that the project is entirely financed by debt. The current effect is twice as high as the one estimated with $\tau^{e e}$, but falls substantially when the lagged tax rates are added. Without controlling for any other firm-level variables, Column (3) actually yields a negative and significant non-transitory response. Once other explanatory variables and year dummies are accounted for in Column (4), the long-run effect is 0.258 , which is higher than the one obtained with the same specification using $\tau^{e e}$. The richest specification in Column (7), however, produces a non-transitory effect of 0.031 , which is not significantly different from zero. Similarly to the regressions with $\tau^{e e}$, the estimates with $\tau^{e d}$ lead to a long-run response that is either close to zero, or small, positive and significant, depending on the dummy structure.

In general, assuming a project financed by debt results in lower estimated coefficients of the net-of-tax shares in absolute value than a project financed by equity. This may be due to the fact that, unlike financing with equity (retained earnings), the cost of raising external capital through debt, $F$, is different from zero, which in turn yields higher netpresent value $R$ and hence smaller $\tau^{e d}$. Compared to $\tau^{e e}$, the distribution of $\tau^{e d}$ is thus shifted to the left, as shown in Figures 4 and 5. With more values of $\tau^{e d}$ closer to zero, it is not surprising that a flatter line is estimated with this tax rate than with $\tau^{e e}$. 


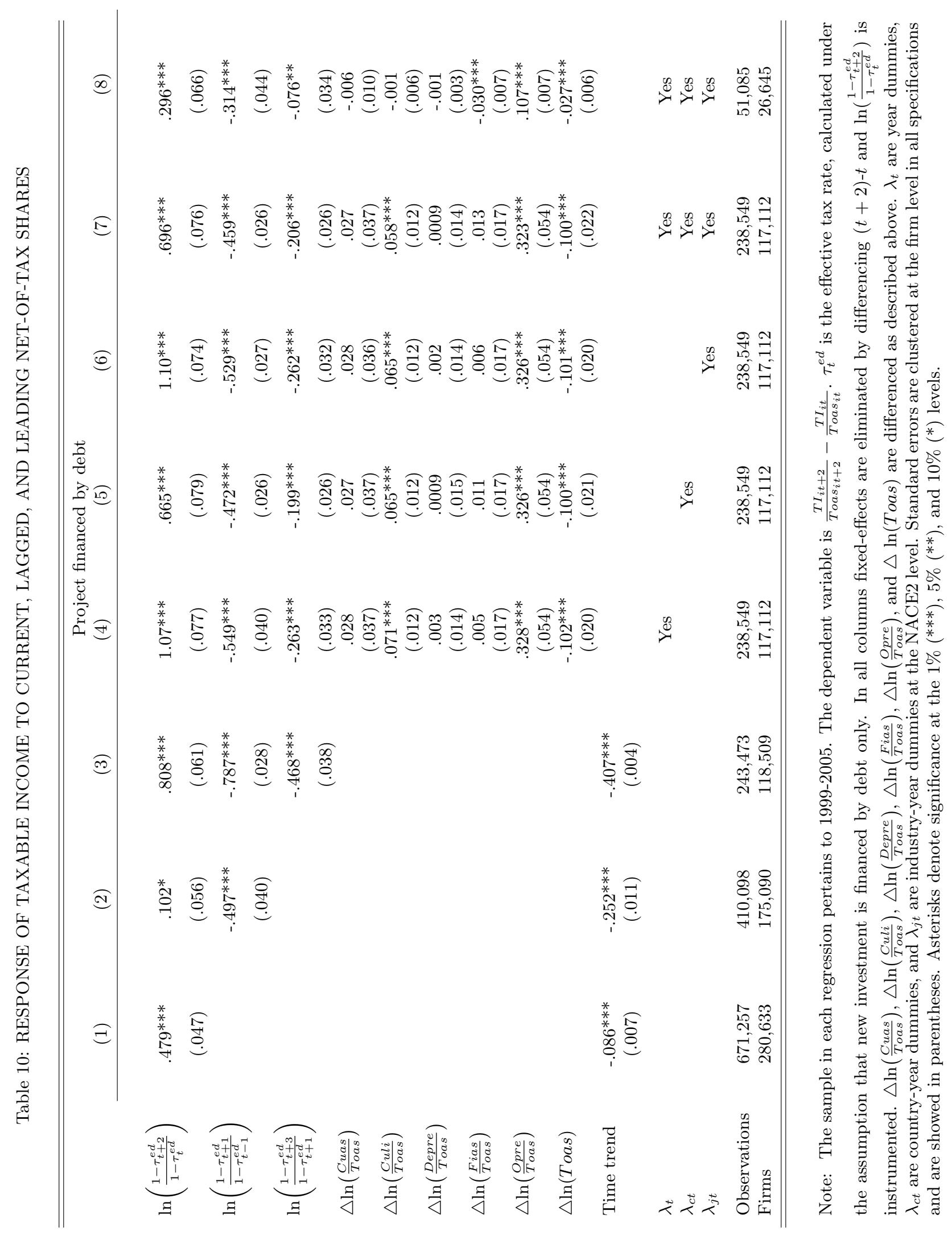




\section{Conclusion}

In the last two decades most $\mathrm{CEE}$ countries undertook radical tax cuts as part of a package of tax reforms speeding up their transition from controlled to competitive market economies. The considerable decline in the CIT rates contributed to a reduction in illicit economic activities, encouraged new entrepreneurs and stimulated already existing firms to expand, thus leading to a remarkable stability of revenue collections.

This paper explores whether firms resort to income shifting across years in anticipation of lower tax rates as an additional mechanism that can explain the increase of corporate revenue in the years taxes were cut. A substantial rise in revenue in a tax cut year occurs at the expense of previous year collections if income shifting is present. Further, if tax declines are expected in the future, taxable income can be shifted further.

The shifting of income, however, is simply a timing response that does not distort real economic behaviour, and, if unaccounted for, would wrongfully inflate the deadweight loss of the CIT. Thus, the estimates of the current effect of the net-of-tax shares yield large coefficients, implying a 0.01 increase in the difference of the taxable income-total assets ratio as a result of a $1 \%$ increase in the two year difference between the net-oftax rates. Given an average $\frac{T I}{\text { Toas }}$ ratio of 0.08 , a 0.01 increase is substantial. When the possibility of income shifting is explicitly modelled by the inclusion of leading and lagged terms, the sum of the three coefficients is in the range between zero and .15 (.20 if $\tau^{e d}$ estimates are considered). Nevertheless, even the positive estimated non-transitory responses have a negligible effect on $\frac{T I}{T o a s}$ as compared to the current response only.

The results suggest that small firms are most responsive to anticipated tax cuts, exhibiting the largest shifting coefficients as well as the largest long-term response, followed by medium enterprises. In contrast, the estimated current effect for big firms is negative, leading to negative and significant permanent responses. This finding is to some extent mimicked by country sample splits, since the subsamples for five of the CEE countries, Romania being excluded, are composed largely of medium and Top 250,000 firms, mainly due to the requirement that a firm appears in the panel for at least five years. For this reason, outside of the sample results, it cannot be conclusively stated that the estimates for the Czech Republic and Poland are smaller than for Romania because firms there are less responsive to tax changes, or that firms in Bulgaria, Hungary, and Slovakia behave differently given the negatively estimated current effects. 


\section{References}

Bond, S., 2002. Dynamic panel data models: A guide to micro data methods and practice. Working Paper CWP09/02, CEMMAP, London,UK.

Cameron, A. C., Trivedi, P. K., 2009a. Microeconometrics. Methods and Applications. Cambridge University Press, New York, NY.

Cameron, A. C., Trivedi, P. K., 2009b. Microeconometrics Using Stata. Stata Press, College Station, TX.

Clausing, K. A., 2007. Corporate tax revenues in OECD countries. International Tax and Public Finance 14 (2), 115-133.

Da Rin, M., Di Giacomo, M., Sembenelli, A., 2011. Entrepreneurship, firm entry, and the taxation of corporate income: Evidence from Europe. Journal of Public Economics 95 (9-10), 1048-1066.

Devereux, M. P., Griffith, R., 2003. Evaluating tax policy for location decisions. International Tax and Public Finance 10 (2), 107-126.

Devereux, M. P., Griffith, R., Klemm, A., 2004. Why has the UK corporation tax raised so much revenue? Fiscal Studies 25 (4), 367-388.

Dwenger, N., Steiner, V., 2012. Profit taxation and the elasticity of the corporate income tax base: Evidence from German corporate tax return data. National Tax Journal, forthcoming.

Ernst $\mathscr{E}$ Young, Various years. Worldwide corporate tax guide. Ernst $\mathscr{E}$ Young.

European Commission, 2010. Green paper on the future of VAT. Towards a simpler, more robust and efficient VAT system. COM(2010)695 SEC(2010)1455, Brussels.

European Commission, Various years. Taxation trends in the European Union. Data for the EU member states, Iceland and Norway. Publications office of the European Union, Luxembourg.

Goolsbee, A., 2000. What happens when you tax the rich? Evidence from executive compensation. Journal of Political Economy 108 (2), 352-378.

Gruber, J., Rauh, J., 2007. How elastic is the corporate income tax base? In: Auerbach, A., Hines, J., Slemrod, J. (Eds.), Taxing Corporate Income in the 21st Century. Cambridge University Press, Cambridge, UK, pp. 140-163. 
Guenther, D. A., 1994. Earnings management in response to corporate tax rate changes: Evidence from the 1986 Tax Reform Act. The Accounting Review 69 (1), 230-243.

Hanlon, M., 2003. What can we infer about a firm's taxable income from its financial statements? National Tax Journal 56 (4), 831-863.

Heim, B. T., 2006. The elasticity of taxable income: Evidence from a new panel of tax returns. Office of Tax Analysis Working Paper, Washington, DC.

Kalwij, A. S., 2003. A maximum likelihood estimator based on first differences for panel data Tobit model with individual specific effects. Economic Letters 81 (6), 165-172.

King, M. A., 1974. Taxation and the cost of capital. The Review of Economic Studies 41 (1), 21-35.

Klapper, L., Laeven, L., Rajan, R., 2006. Entry regulation as a barrier to entrepreneurship. Journal of Financial Economics 82 (3), 591-629.

KPMG Poland, 2009. A guide to special economic zones in Poland. KPMG.

Mintz, J. M., 1988. An empirical estimate of corporate tax refundability and effective tax rates. Quarterly Journal of Economics 103 (1), 225-231.

Nickell, S., 1981. Biases in dynamic models with fixed effects. Econometrica 49 (6), 14171426.

Piotrowska, J., Vanborren, W., 2008. The corporate income tax rate-revenue paradox: Evidence in the EU. Working Paper 12, Brussels.

Roubi, R. R., Richardson, A. W., 1998. Managing discretionary accruals in response to reductions in corporate tax rates in Canada, Malaysia and Singapore. The International Journal of Accounting 33 (4), 455-467.

Scholes, M. S., Wilson, G. P., Wolfson, M. A., 1992. Firms' responses to anticipated reductions in tax rates: The Tax Reform Act of 1986. Journal of Accounting Research 30, 161-185.

Slemrod, J., 1995. Income creation or income shifting? Behavioral responses to the Tax Reform Act of 1986 . A.E.A. Papers and Proceedings 85 (2), 175-180.

Smart, M., Hong, Q., 2010. In praise of tax havens: International tax planning and foreign direct investment. European Economic Review 54 (1), 82-95. 
Tang, J., Jog, V. M., 2001. Tax reforms, debt shifting and tax revenues: Multinational corporations in Canada. International Tax and Public Finance 8 (1), 5-25.

United Nations, 2000. Tax incentives and foreign direct investment: A global survey. ASIT Advisory Studies No. 16, Geneva. 


\section{Appendix A.1}

Table 11: CHANGE IN THE NUMBER OF ENTERPRISES BY SECTOR

\begin{tabular}{|c|c|c|c|c|c|c|c|}
\hline & 1999 & 2000 & 2001 & 2002 & 2003 & 2004 & 2005 \\
\hline \multicolumn{8}{|l|}{ BG } \\
\hline Mining \& quarry & & & & 187 & 207 & 228 & 250 \\
\hline Electricity, gas, water supply & & & & 181 & 214 & 247 & 279 \\
\hline Hotels \& restaurants & & & & 22,833 & 23,258 & 23,135 & 22,655 \\
\hline Transport, communications & & & & 24,203 & 24,196 & 22,853 & 22,206 \\
\hline Manufacturing & & & & 25,689 & 27,603 & 28,730 & 28,740 \\
\hline Construction & & & & 16,986 & 16,824 & 14,250 & 12,823 \\
\hline $\mathrm{W} /$ sale \& retail & & & & 119,501 & 124,051 & 125,500 & 123,740 \\
\hline Real estate, business & & & & 21,379 & 23,728 & 25,465 & 29,622 \\
\hline \multicolumn{8}{|l|}{$\mathrm{CZ}$} \\
\hline Mining \& quarry & 301 & 241 & 244 & 317 & 285 & 427 & 324 \\
\hline Electricity, gas, water supply & 668 & 862 & 707 & 942 & 883 & 1,066 & 1,083 \\
\hline Hotels \& restaurants & 38,408 & 41,721 & 42,580 & 47,777 & 48,800 & 50,254 & 50,233 \\
\hline Transport, communications & 39,531 & 62,002 & 40,828 & 46,739 & 46,362 & 46,851 & 45,739 \\
\hline Manufacturing & 136,206 & 144,099 & 131,582 & 153,788 & 153,131 & 151,252 & 149,581 \\
\hline Construction & 110,813 & 126,040 & 119,764 & 144,038 & 147,790 & 150,474 & 144,177 \\
\hline $\mathrm{W} /$ sale \& retail & 215,456 & 234,686 & 205,514 & 237,088 & 233,560 & 227,419 & 218,839 \\
\hline Real estate, business & 174,684 & 190,727 & 200,543 & 245,801 & 245,824 & 251,906 & 246,008 \\
\hline \multicolumn{8}{|l|}{$\mathrm{HU}$} \\
\hline Mining \& quarry & & & 418 & 412 & 457 & 455 & 456 \\
\hline Electricity, gas, water supply & & & 514 & 515 & 593 & 630 & 651 \\
\hline Hotels \& restaurants & & & 32,121 & 32,966 & 35,320 & 33,568 & 32,815 \\
\hline Transport, communications & & & 40,644 & 40,207 & 38,947 & 38,160 & 36,882 \\
\hline Manufacturing & & & 75,219 & 73,005 & 69,711 & 68,042 & 64,956 \\
\hline Construction & & & 63,982 & 65,857 & 69,667 & 71,951 & 71,431 \\
\hline $\mathrm{W} /$ sale \& retail & & & 173,955 & 170,135 & 169,109 & 161,054 & 156,100 \\
\hline Real estate, business & & & 161,606 & 174,446 & 171,562 & 189,900 & 193,928 \\
\hline \multicolumn{8}{|l|}{ PL } \\
\hline Mining \& quarry & 1,058 & 1,272 & 1,373 & 1,505 & 1,123 & 1,176 & 1,243 \\
\hline Electricity, gas, water supply & 1,791 & 1,929 & 1,839 & 2,086 & 1,758 & 1,931 & 2,078 \\
\hline Hotels \& restaurants & 58,461 & 57,664 & 51,645 & 55,685 & 57,142 & 56,614 & 57,146 \\
\hline Transport, communications & 169,878 & 158,296 & 147,533 & 152,201 & 144,974 & 142,119 & 136,385 \\
\hline Manufacturing & 243,347 & 219,313 & 199,993 & 210,200 & 197,397 & 207,197 & 191,561 \\
\hline Construction & 214,264 & 205,047 & 174,843 & 183,372 & 170,295 & 159,958 & 160,227 \\
\hline $\mathrm{W} /$ sale \& retail & 677,616 & 653,712 & 589,115 & 626,219 & 614,700 & 610,977 & 591,137 \\
\hline Real estate, business & 213,644 & 236,731 & 250,801 & 267,049 & 270,098 & 277,099 & 267,572 \\
\hline
\end{tabular}

$\mathrm{RO}$

See Figure 1 for trend in total enterprises

SK

Mining \& quarry

Electricity, gas, water supply

Hotels \& restaurants

Transport, communications

Manufacturing

Construction

$\mathrm{W} /$ sale \& retail

$\begin{array}{ccc}69 & 70 & 68 \\ 120 & 130 & 166 \\ 740 & 1,161 & 792 \\ 1,184 & 1,531 & 1,179 \\ 5,614 & 6,368 & 5,609 \\ 2,911 & 3,691 & 2,738 \\ 12,473 & 15,465 & 11,828 \\ 6,089 & 8,494 & 6,527\end{array}$

$\begin{array}{ccc}78 & 81 & 81 \\ 153 & 182 & 207 \\ 1,141 & 1,260 & 1,424 \\ 1,399 & 1,530 & 1,951 \\ 6,764 & 6,389 & 6,848 \\ 3,590 & 3,254 & 3,724 \\ 14,730 & 13,872 & 16,899 \\ 9,372 & 9,111 & 11,089\end{array}$

Real estate, business

6,089

Source: OECD SDBS Structural Business Statistics: All Businesses (SSIS) for the Czech Republic, Hungary, Poland, and Slovakia; Bulgarian National Statistical Institute, Structural Business Statistics for Bulgaria; Eurostat Business Demography Statistics for Romania and Hungary. 
Table 12: CHANGE IN PROFITABILITY BY SECTOR

\begin{tabular}{|c|c|c|c|c|c|c|c|}
\hline & 1999 & 2000 & 2001 & 2002 & 2003 & 2004 & 2005 \\
\hline \multicolumn{8}{|l|}{ BG } \\
\hline Mining \& quarry & 0.383 & 0.163 & -0.222 & -0.323 & 0.034 & 0.169 & 0.288 \\
\hline Electricity, gas, water supply & 0.400 & 0.523 & 0.402 & 0.314 & 0.201 & 0.235 & 0.137 \\
\hline Hotels \& restaurants & 0.575 & 0.548 & 0.504 & 0.457 & 0.407 & 0.453 & 0.388 \\
\hline Transport, communications & 0.347 & 0.554 & 0.450 & 0.465 & 0.476 & 0.480 & 0.431 \\
\hline Manufacturing & 0.167 & 0.283 & 0.300 & 0.280 & 0.283 & 0.281 & 0.286 \\
\hline Construction & 0.501 & 0.520 & 0.508 & 0.484 & 0.446 & 0.509 & 0.517 \\
\hline $\mathrm{W} /$ sale \& retail & 0.495 & 0.474 & 0.472 & 0.414 & 0.270 & 0.303 & 0.356 \\
\hline Real estate, business & 0.817 & 0.805 & 0.780 & 0.779 & 0.76 & 0.745 & 0.722 \\
\hline \multicolumn{8}{|l|}{$\mathrm{CZ}$} \\
\hline Mining \& quarry & 0.372 & 0.212 & 0.232 & 0.209 & 0.194 & 0.326 & 0.393 \\
\hline Electricity, gas, water supply & 0.136 & -0.024 & 0.102 & 0.149 & 0.207 & 0.281 & 0.327 \\
\hline Hotels \& restaurants & 0.487 & 0.426 & 0.379 & 0.361 & 0.420 & 0.448 & 0.392 \\
\hline Transport, communications & 0.273 & 0.256 & 0.288 & 0.325 & 0.336 & 0.303 & 0.270 \\
\hline Manufacturing & 0.342 & 0.345 & 0.325 & 0.230 & 0.287 & 0.342 & 0.331 \\
\hline Construction & 0.408 & 0.402 & 0.417 & 0.407 & 0.421 & 0.440 & 0.429 \\
\hline $\mathrm{W} /$ sale \& retail & 0.440 & 0.478 & 0.464 & 0.479 & 0.445 & 0.380 & 0.439 \\
\hline Real estate, business & 0.414 & 0.431 & 0.426 & 0.404 & 0.388 & 0.377 & 0.399 \\
\hline \multicolumn{8}{|l|}{$\mathrm{HU}$} \\
\hline Mining \& quarry & -0.271 & -0.220 & -0.349 & -0.104 & -0.068 & -0.030 & 0.034 \\
\hline Electricity, gas, water supply & 0.205 & 0.155 & 0.104 & 0.111 & 0.120 & 0.188 & 0.137 \\
\hline Hotels \& restaurants & 0.361 & 0.278 & 0.246 & 0.280 & 0.200 & 0.182 & 0.160 \\
\hline Transport, communications & 0.069 & 0.034 & 0.053 & 0.113 & 0.125 & 0.147 & 0.128 \\
\hline Manufacturing & 0.311 & 0.287 & 0.288 & 0.303 & 0.326 & 0.351 & 0.346 \\
\hline Construction & 0.449 & 0.464 & 0.461 & 0.481 & 0.418 & 0.417 & 0.371 \\
\hline $\mathrm{W} /$ sale \& retail & 0.335 & 0.271 & 0.355 & 0.373 & 0.312 & 0.292 & 0.276 \\
\hline Real estate, business & 0.478 & 0.474 & 0.479 & 0.487 & 0.459 & 0.443 & 0.425 \\
\hline \multicolumn{8}{|l|}{$\mathrm{PL}$} \\
\hline Mining \& quarry & -0.187 & -0.008 & -0.038 & -0.075 & -0.045 & 0.201 & 0.225 \\
\hline Electricity, gas, water supply & -0.266 & -0.296 & -0.176 & -0.082 & -0.005 & -0.015 & -0.014 \\
\hline Hotels \& restaurants & 0.424 & 0.419 & 0.396 & 0.457 & 0.458 & 0.441 & 0.457 \\
\hline Transport, communications & 0.165 & 0.200 & 0.241 & 0.296 & 0.303 & 0.334 & 0.350 \\
\hline Manufacturing & 0.169 & 0.191 & 0.160 & 0.188 & 0.260 & 0.340 & 0.328 \\
\hline Construction & 0.518 & 0.531 & 0.475 & 0.505 & 0.552 & 0.554 & 0.574 \\
\hline $\mathrm{W} /$ sale \& retail & 0.695 & 0.700 & 0.675 & 0.681 & 0.651 & 0.683 & 0.676 \\
\hline Real estate, business & 0.615 & 0.620 & 0.595 & 0.608 & 0.619 & 0.613 & 0.627 \\
\hline \multicolumn{8}{|l|}{$\mathrm{RO}$} \\
\hline Mining \& quarry & 0.304 & 0.357 & 0.161 & 0.184 & 0.209 & 0.191 & 0.143 \\
\hline Electricity, gas, water supply & 0.505 & 0.449 & 0.275 & 0.471 & 0.510 & 0.496 & 0.442 \\
\hline Hotels \& restaurants & 0.854 & 0.747 & 0.502 & 0.576 & 0.592 & 0.578 & 0.605 \\
\hline Transport, communications & 0.725 & 0.564 & 0.550 & 0.581 & 0.620 & 0.654 & 0.626 \\
\hline Manufacturing & 0.517 & 0.489 & 0.439 & 0.479 & 0.477 & 0.505 & 0.478 \\
\hline Construction & 0.574 & 0.541 & 0.422 & 0.477 & 0.574 & 0.569 & 0.582 \\
\hline $\mathrm{W} /$ sale \& retail & 0.664 & 0.529 & 0.505 & 0.507 & 0.574 & 0.588 & 0.592 \\
\hline Real estate, business & 0.869 & 0.869 & 0.802 & 0.828 & 0.849 & 0.825 & 0.828 \\
\hline \multicolumn{8}{|l|}{ SK } \\
\hline Mining \& quarry & 0.205 & 0.318 & 0.274 & 0.125 & 0.219 & 0.177 & 0.224 \\
\hline Electricity, gas, water supply & 0.103 & -0.290 & -1.03 & -0.542 & -0.059 & 0.127 & 0.021 \\
\hline Hotels \& restaurants & 0.451 & 0.442 & 0.425 & 0.385 & 0.416 & 0.445 & 0.462 \\
\hline Transport, communications & 0.417 & 0.415 & 0.475 & 0.398 & 0.375 & 0.368 & 0.350 \\
\hline Manufacturing & 0.321 & 0.347 & 0.37 & 0.315 & 0.329 & 0.393 & 0.394 \\
\hline Construction & 0.457 & 0.607 & 0.575 & 0.645 & 0.559 & 0.568 & 0.601 \\
\hline $\mathrm{W} /$ sale \& retail & 0.493 & 0.355 & 0.469 & 0.394 & 0.508 & 0.553 & 0.529 \\
\hline Real estate, business & 0.455 & 0.458 & 0.458 & 0.485 & 0.440 & 0.454 & 0.407 \\
\hline
\end{tabular}

Profitability is measured as corporate net operating surplus divided by corporate value added. Source Eurostat. 


\section{Appendix A.2: Identifying firms eligible for tax incentives}

The Ernst \& Young Worldwide corporate tax guides provide a comprehensive list of the tax incentives introduced over the period 1999-2005. Due to the nature of the qualifying conditions and data availability, only a subset of these incentives are accounted for, which are summarised in Table 2. For convenience, I repeat the reforms and eligibility criteria below and explain how I have identified firms in the AMADEUS dataset that are eligible or have used a tax break. The main assumption is that if a firm met the conditions for a tax incentive, it took advantage of it. Nevertheless, this assumption is always double checked by looking at what happens to eligible firms' tax payments.

\section{Bulgaria}

Production companies qualify for a $100 \%$ reduction of the corporate tax on income for five consecutive years if the following conditions are met: a) The company and its assets are located in municipalities with unemployment rate for the preceding year $50 \%$ higher than the average unemployment rate for the country; b) the tax is accounted for as a reserve and (part of it) is used for the acquisition of long-term fixed assets; c) $80 \%$ of workers reside in the above-mentioned municipalities; d) the company does not have outstanding liabilities for tax and social insurance contributions. The tax incentive was introduced at the beginning of 2003 and is still in force.

A list of the municipalities that satisfy the unemployment rate condition is published every year as an annex of the Bulgarian Corporate Income Tax Law. I matched the cities in which manufacturing companies operate to these municipalities as a first step to identifying firms eligible for the tax incentive. I then chose only firms whose fixed assets grew compared to the previous year. Unfortunately, I cannot account for conditions c) and d), but given that a firm satisfies a) and b), and has reported zero (negative) tax and positive accounting profit, I assume that it took advantage of the tax opportunity. Thus, if a firm qualifies in 2003, its effective tax rate is zero for the remaining years it appears in the panel. Approximately 60 firms (254 firm-year observations) meet the above conditions. Since their taxable income cannot be imputed, earnings before interest and tax are used instead (ebit).

The Czech Republic

Investors in manufacturing can apply for corporate income tax holiday for up to 10 years subject to conditions which change annually. For a detailed account of these requirements, see Ernst \& 8 Young (Various years). A list of the qualifying firms for the period 1999-2005 is published at http://www.czechinvest.org/en/investment-incentivesfor-manufacturing-industry. As the AMADEUS dataset includes the names of the com- 
panies, it is straightforward to identify the Czech and Czech-based foreign firms that have been granted the tax holiday. This tax incentive is in force for the whole time period considered in the paper.

From the Czechinvest list, 167 firms altogether appear in the AMADEUS dataset, or equivalently 781 firm-year observations. Out of these, 426 firm-year observations face a zero statutory tax rate. This is because some firms appear in the data a few years before they qualified for the tax holiday. Similarly to Bulgarian firms, ebit is used as a measure of these firms' TI for the relevant years. In 1999 and 2000, only firms belonging to the Top 250,000 firms took advantage of the tax holiday. From 2002 onwards, smaller companies also joined in utilising the incentive. All of them are part of Dataset M (Top 1.5 million firms). AMADEUS's criteria for Top 250,000 and Top 1.5m firms are described under Table 8 and in the main text.

Over $20 \%$ of all firms granted the tax holiday specialise in the manufacture of parts and accessories for motor vehicles and their engines (NACE4 3430) and the manufacture of electrical equipment for engines and vehicles (NACE4 3161).

\section{Hungary}

Hungary offers an investment tax credit of $50 \%$ of the corporate tax for two sectors: manufacturing and the hotel industry. To qualify for the credit, a manufacturing firm should make an investment of HUF 1 billion ( $\$ 3.33$ million). The credit can be claimed in each of the next consecutive five years if sales revenue increases by an annual average of $5 \%$ of the investment value (Ernst 8 Young, Various years). Given the conditions, I identify manufacturing firms (52 firms, 167 firm-year observations), whose fixed assets grew by at least the minimum amount required and assigned $50 \%$ lower statutory tax rate for the subsequent years these firms show in the panel, provided that their sales increased by at least $5 \%$ of the minimum investment required.

With respect to hotels, the same amount of investment is necessary - HUF 1 billion. However, in order to claim the credit in the next 5 years, sales should grow by $25 \%$ compared to previous year sales but not less than HUF 600 million. Approximately 5-6 hotels meet the investment requirement per year in the AMADEUS database, but none of them meets the sales growth requirement.

\section{Poland}

Poland has fourteen special economic zones, namely Kamienna Góra, Katowice, Kostrzyn-Słubice, Kraków, Legnica, Łódź, Mielec, Pomeranian, Słupsk, Starachowice, Suwałki, Tarnobrzeg, Wałbrzych, and Warmia-Mazury. They are described in detail in KPMG Poland (2009). I obtained a list of the investors for each zone from the zone's respective website and matched it to the data. 
The AMADEUS dataset contains 272 companies (717 firm-year observations) with a license to operate in one or more of the above zones. Together, these firms employ approximately 110,000 people and have $\$ 38$ million of total assets, on average. Given the investment a company makes, it qualifies for a tax exemption based on the following formula: $I=R(€ 50$ million $+0.5 B+0.34 C)$, where $\mathrm{R}$ is the aid intensity in a given economic zone, $\mathrm{B}$ is the amount of investment above $€ 50$ million $(B \leq € 50$ million), while $\mathrm{C}$ is the amount of investment exceeding $€ 100$ million. Thus, a firm investing $€ 120$ million in Slaskie voivodship is eligible for $I=40 \%$ (€50 million $+0.5 € 50$ million $+0.34 € 20$ million $)=€ 32.7$ million exemption and the firm will not pay corporate tax until this exemption has been exhausted (KPMG Poland, 2009). I use ebit as a measure of what these companies' TI is, even in the years they pay some tax because information on the amount of the credits is unavailable.

\section{Romania}

From 2000 to 2004 inclusive, Romania provided incentives for small and medium enterprises. SMEs CIT was reduced by $20 \%$ if their number of employees increased by $10 \%$ as compared to the preceding year. A SME is defined as a firm that has an annual turnover of less than $€ 8$ million and employs no more than 250 employees. Another condition is that the capital of a SME is $100 \%$ privately owned. I isolated firms meeting the employment, turnover and ownership conditions and lowered their statutory tax rates by $20 \%$ if their number of employees grew with the required percent. Tax incentives for SMEs were still available in 2005 but depended on profits reinvested in equipment, and therefore, I am not able to account for them.

About 9,000 firms (42,909 firm-year observations) per year qualified for this incentive, with turnover of $\$ 1$ million and 38 employees, on average. Close to $40 \%$ of the eligible companies were from the retail and wholesale industry. A statutory tax rate of $20 \%$ is assigned on a year-to-year basis to the SMEs, which fulfilled the incentive criteria.

Romania also introduced temporary provisions for microenterprises from 2001 to 2002, inclusive. A microenterprise is a firm that has no more than 9 employees, annual turnover at most $€ 100,000$, and $100 \%$ privately owned capital. It is taxed at a rate of $1.5 \%$ on all income and in addition, can benefit from the same tax incentive as the one for SMEs. In the initial year, 2001, 78,442 firms qualify in the AMADEUS dataset, more than $50 \%$ of which operate in the retail and wholesale sectors. Interestingly, most of these firms reported zero taxable incomes in 2002, thus reducing the number of companies that could use the incentive to 5,042. A typical microenterprise in 2001 had an annual turnover of $\$ 26,000$ and 3 employees.

Slovakia 
For the period under consideration, Slovakia offered numerous tax incentives, such as $100 \%$ corporate tax credit, especially for companies with a given percent of foreign ownership of paid-up registered capital. Due to the large number of qualifying conditions, however, I are not able to pinpoint these firms in the AMADEUS data (Ernst 86 Young, Various years). 


\title{
Appendix A.3: Description of variables used in the compu- tation of EATR
}

\author{
Table 13: VARIABLES DEFINITION, FORMULAS AND SOURCES
}
$p \quad$ Financial rate of return, firm-level variable, equal to [Added Value - Labour Expenses]/Added Value. Added Value equals taxes paid taxa + profit/loss for the period $p l+$ depreciation depre + interest paid inte + labour expenses staf. For reasons explained in Section 4.2, inte is not included in the calculation of $p$. Source AMADEUS.

$i \quad$ Nominal interest rate, country-level variable. For Bulgaria, Poland and Slovakia it equals the two-year government bond rate, one year government bond rate for the Czech Republic, one year treasury bill for Hungary and the money market interest rate for Romania. Source: Central Banks of Bulgaria, the Czech Republic, Hungary, Poland; European Central Bank and Eurostat.

$\pi \quad$ Inflation rate, country-level variable. Measured with the Harmonised Indices of Consumer Prices. Source Eurostat.

$r \quad$ Real interest rate. $r=\frac{i-\pi}{1+\pi}$, country-level variable. Author's calculation.

$\tau^{s} \quad$ Statutory corporate tax rate, country-level variable for firms with positive taxable income, although it becomes zero for firms with losses (carryforward), zero profit, or tax incentives, so it is also firm-specific. For a few years, $\tau^{s}$ in Bulgaria also varied based on a given threshold of taxable income. Source Ernst $\&$ Young (Various years) and European Commission (Various years).

$m^{i} \quad$ Tax rate on interest income, for example interest earned on deposits in savings accounts, or income from rental property, etc. I assume $m^{i}=0$.

$m^{d} \quad$ Tax rate on dividend income. I assume $m^{d}=0$.

$z \quad$ Tax rate on capital gains, on an accrual basis. I assume $z=0$.

$c \quad$ Rate of tax credit on dividends. The tax credit reduces the tax liability of the person receiving the dividends in order to avoid double taxation of the dividends. I assume $c=0$.

$\theta \quad \theta=\left(1-m^{d}\right) /(1-c)(1-z)$. King (1974) defines $\theta$ as the opportunity cost of retained earnings in terms of net dividends foregone, or the amount which shareholders would gain if one unit of retained earnings were distributed. $\theta$ is derived from the capital market equilibrium condition eq.(2). As I assume that $m^{d}=c=z=0$, then $\theta=1$, i.e. cash held by the company or by the shareholders can be interchanged without incurring additional tax liability.

$\rho \quad \rho=\left(1-m^{i}\right) * i /(1-z)$ is the discount factor of the dividend stream. See Section 4.2. Given the assumption that $m^{i}=z=0$, the discount factor is equal to the nominal interest rate $i$.

$\phi \quad$ Depreciation rate of capital, country-level variable. I use the maximum depreciation rate for plant and machinery in the case of Poland and Hungary, heavy machinery for the Czech Republic and Slovakia, machines and manufacturing equipment for Bulgaria and Romania. See Table 3 for detailed account of the various asset categories and their depreciation rates. Source Ernst $\&$ Young (Various years).

$\delta \quad$ One period cost of depreciation, assumed to be $12.5 \%$. See Da Rin et al. (2011).

$R^{*} \quad$ Net present value of the investment project without tax. $R^{*}=-1+\frac{1}{1+i}[(p+\delta)(1+\pi)+$ $(1-\delta)(1+\pi)]=\frac{p-r}{1+r}$, where the second equality comes from the fact that $r=\frac{i-\pi}{1+\pi}$ and the assumption that $m^{d}=c=z=m^{i}=0$. Author's calculation.

$R \quad$ Net present value of the project with tax. The general formula for $R$ is $R=\frac{\theta}{1+\rho}[(p+\delta)(1+$ $\left.\pi)\left(1-\tau^{s}\right)-((1+\rho)-(1-\delta)(1+\pi))(1-A)\right]+F$, which simplifies to $R=\frac{1}{1+i}[(p+\delta)(1+\pi)(1-$ $\left.\left.\tau^{s}\right)-((1+i)-(1-\delta)(1+\pi))(1-A)\right]+F$, given that $\rho=i$ and $\theta=1 . A$ is the NPV of tax allowances per unit of investment and $A=\phi \tau^{s} \frac{(1+i)}{i}\left(1-\frac{1}{(1+i)^{T+1}}\right)$, based on $\rho=i$, for straightline depreciation and $T=1 / \phi$. Although some countries allow for accelerated depreciation, the straight-line method is always the baseline and is the method used in the paper. $F$ is the cost of raising external capital. Thus $F=0$ in case of retained earnings, and $F=\frac{-\rho(1-\theta)}{1+\rho}\left(1-\phi \tau^{s}\right)=0$ for equity as $\theta=1$. $F=0$ for both equity and retained earnings reflects the discussion on $\theta$ above. If capital is raised by debt, then $F=\frac{\theta\left(1-\phi \tau^{s}\right)}{1+\rho}\left(\rho-i\left(1-\tau^{s}\right)\right)=i \tau^{s} \frac{1-\phi \tau^{s}}{1+i}$, which is exactly the amount of deductible interest payments, if the firm has borrowed $1-\phi \tau^{s}$. Author's calculation.

EATR Effective average tax rate, firm-level variable. $E A T R_{\text {debt }}=\frac{\left(R^{*}-R\right)(1+r)}{p} \equiv \tau^{e d}$ for debt and $E A T R_{\text {equity }}=\left.\frac{\left(R^{*}-R\right)(1+r)}{p}\right|_{F=0} \equiv \tau^{e e}$ for equity (retained earnings). Bearing in mind that $F=0$ for equity, $E A \stackrel{p}{T} R_{\text {equity }}>E A T R_{\text {debt }}$. Author's calculation. 


\section{Working Paper Series}

ISSN 1211-3298

Registration No. (Ministry of Culture): E 19443

Specific research support and/or other grants the researchers/publications benefited from are acknowledged at the beginning of the Paper.

(c) Boryana Madzharova, 2012

All rights reserved. No part of this publication may be reproduced, stored in a retrieval system or transmitted in any form or by any means, electronic, mechanical or photocopying, recording, or otherwise without the prior permission of the publisher.

Published by

Charles University in Prague, Center for Economic Research and Graduate Education (CERGE) and

Economics Institute ASCR, v. v. i. (EI)

CERGE-EI, Politických vězňů 7, 11121 Prague 1, tel.: +420 224005 153, Czech Republic.

Printed by CERGE-EI, Prague

Subscription: CERGE-EI homepage: http://www.cerge-ei.cz

Phone: + 420224005153

Email: office@cerge-ei.cz

Web: http://www.cerge-ei.cz

Editor: Michal Kejak

Editorial board: Jan Kmenta, Randall Filer, Petr Zemčík

The paper is available online at http://www.cerge-ei.cz/publications/working_papers/.

ISBN 978-80-7343-265-2 (Univerzita Karlova. Centrum pro ekonomický výzkum a doktorské studium)

ISBN 978-80-7344-257-6 (Národohospodářský ústav AV ČR, v. v. i.) 
CERGE-EI

P.O.BOX 882

Politických vězňů 7

11121 Praha 1

Czech Republic http://www.cerge-ei.cz 